\title{
Characterizing the evolution of physical properties and mixing state of black carbon particles: from near a major highway to the broader urban plume in Los Angeles
}

\author{
Trevor S. Krasowsky ${ }^{1}$, Gavin R. McMeeking ${ }^{2}$, Constantinos Sioutas ${ }^{1}$, and George Ban-Weiss ${ }^{1}$ \\ ${ }^{1}$ Department of Civil and Environmental Engineering, University of Southern California, \\ Los Angeles, 90089, USA \\ ${ }^{2}$ Handix Scientific, Boulder, 80301, USA
}

Correspondence: George Ban-Weiss (banweiss@usc.edu)

Received: 1 November 2017 - Discussion started: 9 November 2017

Revised: 9 July 2018 - Accepted: 13 July 2018 - Published: 22 August 2018

\begin{abstract}
Black carbon (BC) particles can have deleterious human health consequences and impact regional and global climate. Uncertainties remain in part due to incomplete knowledge on the evolution of physical properties and mixing state of black carbon from sources to the remote atmosphere. We aim to understand how "road-to-ambient" processing and longer timescale aging in an urban plume affect black carbon physical properties. Refractory black carbon (rBC) was measured during summer 2016 using a singleparticle soot photometer (SP2) in two distinct environments: near a major freeway and downwind of downtown Los Angeles. The near-road measurements were made at distances ranging from 30 to $114 \mathrm{~m}$ downwind of Interstate 405 in Los Angeles. These results were compared with measurements performed $100 \mathrm{~km}$ east of Los Angeles in Redlands, California. Coatings on $\mathrm{rBC}$ particles were quantified using two methods. As distance from the highway increased at the nearroad site, we observed decreases in $\mathrm{rBC}$ mass and number concentrations and increases in the number fraction of $\mathrm{rBC}$ particles with thick coatings $(f)$. The latter likely occurred due to rapid processing of the highway plume and entrainment of urban background particles. Most rBC-containing particles measured near the highway were either uncoated or thinly coated. In Redlands, we found that rBC mass concentrations on weekdays were similar to those observed at the furthest measured distance from the highway (114 m). However, rBC number concentrations for the smallest measured sizes were an order of magnitude lower in Redlands than all measured distances from the highway. Observations of $f$ indicate that values in Redlands during periods when estimated
\end{abstract}

photochemical age (PCA) was highest $(6-8 \mathrm{~h})$ were similar to corresponding values at the furthest measured distance from the highway. This suggests that the residence time of air in the Los Angeles Basin under typical summertime conditions measured during this campaign may not be sufficient for $\mathrm{rBC}$ to acquire thick coatings. However, under certain meteorological conditions, $f$ was observed to be $\sim 0.20$ in Redlands, with coating thickness histograms showing a larger contribution of $\mathrm{rBC}$ particles with coating thickness $>80 \mathrm{~nm}$. This occurred during a weekend day when local emissions from diesel vehicles were lower (compared to weekdays) and winds brought air from the desert regions to Redlands, both of which would increase the relative contribution of remote sources of $\mathrm{rBC}$. Afternoon values of $f$ (and $\mathrm{O}_{3}$ ) were found to be systematically higher on weekends than weekdays, suggesting that the "weekend effect" can create more thickly coated rBC particles presumably due to enhanced secondary organic aerosol (SOA) and reduced available $\mathrm{rBC}$ as condensation sites.

\section{Introduction}

Black carbon (BC) is considered the second strongest climate-forcing agent following carbon dioxide $\left(\mathrm{CO}_{2}\right)$ and causes a myriad of pernicious health effects including cancer (Hart et al., 2009; Lloyd and Cackette, 2011; WHO, 2012; Bond et al., 2013). Ambient BC absorbs solar radiation, which leads to overall increases in shortwave radiation being absorbed by the climate system and local atmospheric 
heating with consequences on atmospheric thermodynamics (Cooke and Wilson, 1996; Hansen et al., 1997, 2005; BanWeiss et al., 2012). Through its ability to act as cloud condensation nuclei, BC can also influence cloud microphysics (IPCC, 2007). Estimates of emissions and climate consequences of BC remain uncertain compared to other climateforcing agents (Bond et al., 2013). Unlike long-lived greenhouse gases, which are globally well mixed, BC has a relatively short atmospheric lifetime and is therefore spatially heterogeneous (Sardar et al., 2015; Krasowsky et al., 2014). Improving understanding of spatiotemporal variation (from pollutant source to the remote atmosphere) in BC concentrations and physical properties is critical for reducing uncertainties in quantifying its climate and health impacts.

The mixing state of black carbon describes whether other aerosol species exist as separate particles (i.e., externally mixed) or are attached to (or coated on) BC particles (i.e., internally mixed) (Jacobson, 2001; Willis et al., 2016). Though characterizing the mixing state of ambient black carbon through observations is challenging, there have been recent advances in instrumentation and data analysis methods capable of determining coating thickness in addition to $\mathrm{BC}$ mass and number concentrations and $\mathrm{BC}$ size distributions (e.g., Gao et al., 2007; Moteki and Kondo, 2007). Uncertainties remain in part due to variability in the structure of BC-containing particles (Sedlacek et al., 2012). BC is generally considered externally mixed at the emission source. With time, BC can become internally mixed with other species (e.g., sulfates, nitrates, and organics) in a process often referred to as "aging" (Weingartner et al., 1997; Riemer et al., 2010; Bond et al., 2013; Zhang et al., 2015). Past research has suggested that the mixing state of black carbon at the emissions source can influence the aging of BC even after time for significant atmospheric processing (Willis et al., 2016). Coatings on BC are thought to enhance its mass absorption cross section, a metric describing absorption of radiation normalized by the mass of the particle (Fuller et al., 1999; Lack et al., 2009; Subramanian et al., 2010; Healy et al., 2015). Furthermore, coatings influence the hygroscopicity of BC with significant effects on climate (Laborde et al., 2013; Schwarz et al., 2014) in addition to possible but largely unexplored effects on particle health impacts. Uncoated BC has been shown to be hydrophobic while coated BC has a higher affinity for water (i.e., hydrophilic) (Dahlkötter et al., 2014). This change in hygroscopicity has an influence on BC's ability to act as cloud condensation nuclei with subsequent effects on wet deposition rates and lifetime, but this phenomenon still has associated uncertainties. The high relative humidity in the human lungs (99.5\%) (Ferron et al., 1988; Anselm et al., 1990) suggests a relationship between BC hygroscopicity and lung deposition probability. As BC becomes hydrophilic with acquired coatings, health impacts may be modified due to competition between (1) the decrease in deposition probability as particles in the ultrafine mode (particle diameter $<100 \mathrm{~nm}$ ) grow to the accumulation mode
$(0.1 \mu \mathrm{m}<$ particle diameter $<2.5 \mu \mathrm{m})$ and (2) the potential for coated BC to be more toxic than uncoated BC.

The mixing state of $\mathrm{BC}$ is sensitive to a variety of factors and varies in time and space. Composition and timescales for development of coatings can depend on season and location. As an example of seasonal dependence, one modeling study focusing on southwestern Germany showed that condensation of sulfuric acid dominates aging of BC during the summer season, while the relative importance of ammonium nitrate coatings increases during the winter season (Riemer et al., 2004). A more recent observational study in urban Los Angeles found that $\mathrm{BC}$ coatings are mostly comprised of secondary organic aerosol (SOA) (Lee et al., 2017). Previous observations have also concluded that the mixing state of BC in urban areas can vary for weekdays vs. weekends. The substantial decrease in heavy-duty diesel traffic relative to light-duty vehicles on weekends compared to weekdays has been shown to increase secondary organic aerosol formation. This would lead to a higher ratio of organic aerosol to refractory $\mathrm{BC}$, which could cause the fraction of $\mathrm{BC}$ with thick coatings $(f)$ to be higher on weekends (Metcalf et al., 2012; Krasowsky et al., 2016). Time of day can also influence the mechanisms that create coatings on BC. For example, a recent modeling study suggested that $\mathrm{BC}$ aging over central-eastern China is dominated by condensation of photochemical pollutants while coatings at night occur at slower timescales dominated by coagulation aging (Chen et al., 2017).

The physical properties and mixing state of ambient black carbon can be determined using the single-particle soot photometer (SP2). This instrument uses laser-induced incandescence and scattering to determine (a) refractory black carbon (rBC) mass and number concentrations and size distributions and (b) physical properties of rBC-containing particles including coating thickness (Laborde et al., 2012; Dahlkötter et al., 2014). Two different data analysis techniques can be used with SP2 measurements to describe the mixing state of individual rBC-containing particles. The first is the "lagtime" method, which takes advantage of the time delay between peak scattering and incandescence signal responses to stratify particles as those that are (1) uncoated or "thinly" coated vs. (2) "thickly" coated, based on a selected time delay threshold. rBC-containing particles with time delays greater than the set threshold are deemed as thickly coated and vice versa. Coatings vaporize as rBC-containing particles traverse the laser beam in the SP2. Thus, the second method, called the LEO (leading-edge-only) method, works by reconstructing the Gaussian scattering function of scattering signal response curves (i.e., the scattering signal prior to coating vaporization) using the initial $1 \%$ to $5 \%$ of the measured signal. The LEO method employs measurements from the two-element avalanche photodiode in the SP2 to determine particle position as it traverses the laser beam at a near-fixed velocity. After Mie theory modeling with assumed refractive indices, the reconstructed scattering signal 
is used to quantify coating thickness for internally mixed rBC-containing particles (Gao et al., 2007). For more details on the LEO method see Sect. 2.6. Several studies have used the LEO method or related analyses to quantify coating thickness for internally mixed rBC-containing particles. We summarize these studies in Sect. S1.2 in the Supplement with reference to the following past studies: Liu et al. (2014), Schwarz et al. (2008a, b), Shiraiwa et al. (2008), Taylor et al. (2014), and others. Note that there have been important variations in how the LEO method has been applied in previous literature (e.g., variations in $\mathrm{rBC}$ core size ranges for which coating thicknesses are analyzed), making synthesizing previous investigations difficult. We aim to provide sufficient detail on each study to aid in interpreting differences in analysis techniques and conclusions.

Most previous research on the mixing state of $\mathrm{rBC}$ containing particles focuses on timescales of hours or longer as pollutant plumes advect away from sources (Sect. S1.2). To our knowledge, there is limited prior work assessing the evolution of mixing state on more rapid timescales as pollutants are transported away from sources. Earlier studies have investigated the evolution of particle size distributions (i.e., including all species) during "road-to-ambient" processing (i.e., where highly concentrated aerosols from highway emissions dilute to ambient urban background concentrations). Zhang et al. (2004) showed that condensation, evaporation, and dilution dominate the evolution of aerosol physical properties associated with road-to-ambient processing. Changes in aerosol size on these rapid timescales near sources can be described through the competition of partial pressure and saturation vapor pressure, where particle growth through condensation has been shown to occur beyond $90 \mathrm{~m}$ from a major highway (Zhang et al., 2004). In theory, these processes could also impact the mixing state of $\mathrm{rBC}$. Note that during these more rapid timescales there is likely insufficient time for complex photochemical reactions or coagulation of $\mathrm{rBC}$ with non-refractory material to occur. Coagulation becomes more significant when particle number concentrations are high and/or aging timescales are greater than $10 \mathrm{~h}$ (Riemer et al., 2004), substantiating assertions that particle growth of fresh emissions near a major highway is attributed primarily to condensation of semi-volatile species, with coagulation playing a supporting role (Zhang et al., 2004). One previous study (Willis et al., 2016) used a soot particle aerosol mass spectrometer (SP-AMS) to measure traffic emissions in an urban environment. They found that $\mathrm{BC}$ near emissions sources is internally mixed with hydrocarbon-like aerosols (HOA) as either $\mathrm{rBC}$-rich or HOA-rich, with the majority of measured $\mathrm{BC}$ mass associated with $\mathrm{rBC}$-rich particles. Another study (Lee et al., 2017) investigated the evolution of rBC-containing particles near major highways in the Los Angeles Basin using the ratio of $\mathrm{NO}_{x}$ to $\mathrm{NO}_{y}$ as a surrogate for photochemical age (PCA) of the aerosol. They found that SOA was responsible for substantial coatings on rBC during the day when photochemistry is most important. Note that measurements were made roughly $3 \mathrm{~km}$ ( 2 miles) from the nearest highway, meaning that measured $\mathrm{rBC}$-containing particles included a mix of fresh vehicular emissions along with the greater urban plume. An earlier study by Massoli et al. (2012) reported that, under stable atmospheric conditions, vehicular air pollution becomes relatively well mixed with background air within $150 \mathrm{~m}$ of the Long Island Expressway (Interstate 495) in Queens, New York. This assertion alludes to the difficulty of attributing specific atmospheric processing mechanisms to describe changes in the mixing state of aerosols at locations greater than $150 \mathrm{~m}$ downwind of highways where air masses are heavily influenced by vehicular traffic emissions but not independent of the broader city's plume. Additional measurements are needed at a variety of locations and over a range of aging timescales to develop a comprehensive understanding for how morphology of $\mathrm{rBC}-$ containing particles varies from source to urban, continental, and global scale.

The overarching goal of this study is to systematically compare the evolution of physical properties and mixing state for rBC-containing particles at two distinct spatiotemporal scales: rapid timescales during road-to-ambient processing near a major highway and longer timescales after urban emissions have aged during transport to a measurement site downwind of urban Los Angeles. The evolution of physical properties and mixing state at rapid timescales is investigated by making measurements of $\mathrm{rBC}$-containing particles from 30 to $114 \mathrm{~m}$ downwind of a major highway on the west side of Los Angeles near the Pacific Ocean. This location was chosen to minimize the contribution of the broader urban plume on measurements. (We note that changes in measured microphysical properties at this scale occur due to both processing of freshly emitted particles and entrainment of the broader urban plume. It is not our intent to measure the evolution of mixing state for individual BC particles emitted from the freeway, which would be impossible to observe in the real world. Rather, we aim to observe how the mixing state for the population of measured $\mathrm{BC}$ changes as the plume is processed and dilutes downwind of the freeway.) Longer timescales are investigated here by measuring rBC-containing particles in Redlands, CA, roughly $100 \mathrm{~km}$ downwind (assuming prevailing westerly winds) of downtown Los Angeles. Mass and number concentrations of rBCcontaining particles, $\mathrm{rBC}$ size distributions, the fraction of rBC-containing particles that are thickly coated (i.e., using the lag-time method), and coating thickness histograms (i.e., using the LEO method) are reported. A detailed procedure for how we perform the LEO method is also described in the Supplement. In addition to comparing the mixing state of rBC-containing particles at these two aging timescales, the results reported here investigate the influence of meteorology and vehicle fleet (i.e., weekdays vs. weekends) on the mixing state of $\mathrm{rBC}$-containing particles at the Redlands site. To our knowledge, this is the first study to (i) assess how BC microphysical properties evolve at different distances from a 
freeway and (ii) compare BC microphysical properties near a major source vs. downwind of a megacity using a consistent measurement framework.

\section{Materials and methods}

\subsection{Sampling locations}

Two measurement campaigns were completed in 2016 during the hottest season in southern California. Ambient rBCcontaining particles were measured in two distinct environments: the first campaign was conducted near a major highway in Los Angeles, California (i.e., Interstate 405), while the second campaign was conducted $\sim 100 \mathrm{~km}$ east and generally downwind of downtown Los Angeles (i.e., Redlands, California) in an area where $\mathrm{rBC}$ is presumably more aged relative to locations closer to downtown.

\subsubsection{Near-road campaign}

The near-road campaign was carried out at the Los Angeles National Cemetery, which is adjacent to Interstate 405. This site is on the west side of the Los Angeles Basin, $\sim 7 \mathrm{~km}$ ( $\sim 4$ miles) from the Pacific Ocean, and upwind (assuming the dominant westerly onshore flow) of most of the basin including downtown. A previous study by Zhu et al. (2002) demonstrated that the winds at this site are generally westerly and perpendicular to Interstate 405. See Sect. 2.4.1 for a summary of observed meteorology during our campaign. The Los Angeles National Cemetery is therefore an ideal location for investigating the evolution of $\mathrm{rBC}$ mixing state from road to ambient environments given that measured aerosols over a relatively large area are dominated by highway emissions (Zhang et al., 2004). Adjacent to the cemetery, Interstate 405 runs along a $330^{\circ}$ path or virtually north-south (Zhu et al., 2002). The western (eastern) edge of the Los Angeles National Cemetery is $30 \mathrm{~m}(730 \mathrm{~m})$ from Interstate 405 (Zhu et al., 2002). Measurements were recorded in increments of about $8 \mathrm{~m}(25 \mathrm{ft}$.) beginning at $30 \mathrm{~m}(100 \mathrm{ft}$.) and progressing downwind to $114 \mathrm{~m}$ (375 ft.) from the highway for each day using a mobile platform. As described in Zhu et al. (2002), there was not a true " $0 \mathrm{~m}$ " measurement location given (a) the difficulty of approaching the highway with the mobile platform and (b) the width $(\sim 60 \mathrm{~m})$ of the highway itself (i.e., even if we could have sampled at the edge of the highway, we would have been measuring a mix of particles emitted from the nearest lane to the farthest lane). The fraction of vehicles that is heavy-duty diesel trucks on Interstate 405 is estimated to be about $5 \%$ (Zhang et al., 2004).

\subsubsection{Redlands campaign}

Measurements were made at the South Coast Air Quality Management District's (SCAQMD) Redlands site (500 N. Dearborn St. Redlands, CA 92374). The location is approx- imately $100 \mathrm{~km}$ east of downtown Los Angeles in a neighborhood $\sim 1.5 \mathrm{~km}(\sim 1$ mile) from a major highway (Interstate 10). Therefore, aerosols measured at this location are dominated by a mix of sources: (a) vehicular emissions from the nearby highway and (b) aerosols advected from the greater Los Angeles Basin when winds are westerly, or presumably more aged aerosols from the east when winds are easterly. Instruments were housed in an air-conditioned trailer kept at roughly $24^{\circ} \mathrm{C}\left(75^{\circ} \mathrm{F}\right)$ throughout the campaign.

\subsection{Sampling time periods}

The near-road measurement campaign was completed on four separate days from 12:00 to 14:00 local time. Morning and afternoon rush hour on Interstate 405 causes traffic to slow and even halt. Therefore, we chose a time period between these rush-hour episodes when traffic flow was uncongested and speeds were steady at roughly $105-120 \mathrm{~km} \mathrm{~h}^{-1}$ (65-75 mph) (estimated, not measured). Because the goal of this campaign was to assess $\mathrm{rBC}$ mixing state with respect to distance from the highway, short sampling time periods of $5 \mathrm{~min}$ (per distance from the highway) were used to reduce the influence of other confounding factors, such as changes in traffic flow, wind speed and direction, atmospheric stability, and solar irradiance, that would shift following a typical diurnal cycle. Sampling dates were 4 August, 5 August, 12 September, and 14 September 2016.

The Redlands measurement campaign was completed continuously during the late summer from 16 September to 10 October 2016 using stationary instrumentation with measurements recording $24 \mathrm{~h} \mathrm{day}^{-1}$ to capture diurnal changes in rBC-containing particles.

\subsection{Instrumentation}

During both sampling campaigns, an SP2 (Droplet Measurement Technologies, Boulder, $\mathrm{CO}$ ) was used to quantify the physical characteristics of rBC-containing particles. Briefly, the SP2 measures physical properties of rBC-containing particles by focusing a flow of sample air across a high-intensity intra-cavity $\mathrm{Nd}$ :YAG laser $(\lambda=1064 \mathrm{~nm})$. As an individual rBC-containing particle traverses the cross section of the laser beam, the temperature of the particle increases to the point that any coatings on the $\mathrm{rBC}$ vaporize and the $\mathrm{rBC}$ core incandesces. The SP2 is capable of detecting $\mathrm{rBC}$-containing particles to a lower detection limit of approximately $0.5 \mathrm{fg}$ (Gao et al., 2007; Moteki and Kondo, 2007; Dahlkötter et al., 2014; Krasowsky et al., 2016).

A microAeth (MA) model AE51 (Aeth Labs, San Francisco, CA) was positioned at a fixed location $\sim 35 \mathrm{~m}$ from Interstate 405 to ensure the black carbon mass concentration remained consistent $( \pm 20 \%)$ throughout each $2 \mathrm{~h}$ measurement period. The MA is a handheld aethalometer capable of measuring black carbon mass concentrations in real time. 
Table 1. Observed wind speed and direction for Santa Monica airport, which is $3.9 \mathrm{~km} \mathrm{(2.4} \mathrm{mi)} \mathrm{from} \mathrm{the} \mathrm{near-roadway} \mathrm{measurement} \mathrm{site.}$ Times shown are within 15 min of the near-roadway sampling periods.

\begin{tabular}{lllrr}
\hline Date & Time & Cardinal direction & Degree direction & Speed $\left(\mathrm{m} \mathrm{s}^{-1}\right)$ \\
\hline 4 August 2016 & $12: 51^{\mathrm{b}}$ & SW & $214-236$ & 5.1 \\
Sampling period: & $13: 51$ & WSW & $236-259$ & 5.1 \\
12:26-13:45 & & & \\
\hline 5 August 2016 & & & $214-236$ & 3.6 \\
Sampling period: & $12: 51$ & SW & & \\
12:15-13:31 & & & & 4.1 \\
\hline 12 September 2016 & $12: 51$ & SSW & $191-214$ & 4.6 \\
Sampling period: & $13: 51$ & WSW & $236-259$ & 3.6 \\
12:18-01:36 & & & & 4.1 \\
\hline 14 September 2016 & $11: 51$ & WSW & $236-259$ & \\
Sampling period: & $12: 51$ & SW & & \\
11:59-13:16 & & & & \\
\hline
\end{tabular}

${ }^{\mathrm{a}}$ Time range for measurements of $\mathrm{rBC}$ using the $\mathrm{SP} 2 ;{ }^{\mathrm{b}}$ time stamp for weather observations.

A study completed by De Nazelle et al. (2012) shows good agreement for measurements from the MA when compared to other filter-based black carbon measurements. A correction was applied to the MA data to account for a decrease in measurement efficiency as the filter becomes increasingly loaded when sampling (Kirchstetter et al., 2007).

For the near-road measurement campaign, a standard gasoline-powered vehicle was used to house and transport instrumentation, and measurements were taken when the engine was turned off. The SP2 was powered by a $12 \mathrm{~V}$ deep cycle battery along with a DC to AC power inverter. On each day of the near-road measurement campaign (before and after each day's sampling period), and at the beginning and end of the Redlands measurement campaign, an aerosol generator AG-100 (Droplet Measurement Technologies, Boulder, CO) was used to suspend $269 \mathrm{~nm}$ polystyrene latex spheres (PSLs) (Thermo Scientific, formerly Duke Scientific) in particle-free air. The purely scattering PSLs were measured by the SP2 and used in the LEO analysis to aid in understanding its performance and to verify the position of optical components after transit to a new location. Sampling a known size of purely scattering particles can provide detailed information on where the notch in the split detector occurs as described in Gao et al. (2007). Also see Laborde et al. (2013) for more information. The LEO analysis is further described in Sect. 2.6.

\subsection{Meteorology}

\subsubsection{Meteorology near road}

Temperatures for the near-road measurement campaign were moderate with maximum daily temperatures of $25.6^{\circ} \mathrm{C}$ $\left(78^{\circ} \mathrm{F}\right), 23.9^{\circ} \mathrm{C}\left(75^{\circ} \mathrm{F}\right), 21.7^{\circ} \mathrm{C}\left(71^{\circ} \mathrm{F}\right)$, and $21.7^{\circ} \mathrm{C}\left(71^{\circ} \mathrm{F}\right)$ for 4 August, 5 August, 12 September, and 14 September, re- spectively (Weather Underground, 2016). Winds were westerly, causing pollutants to advect across the cemetery perpendicular to Interstate 405 . Similar wind patterns were reported at the same location in Zhu et al. (2002). Table 1 shows the observed wind speed and direction during the nearroad measurement campaign. Wind data were recorded at the Santa Monica airport, which is $3.9 \mathrm{~km}$ (2.4 mi) from the nearroadway measurement site.

\subsubsection{Meteorology Redlands}

Temperatures for the Redlands measurement campaign ranged from 10.6 to $40.6^{\circ} \mathrm{C}\left(51-105^{\circ} \mathrm{F}\right)$ (Weather Underground, 2016). For most days, winds were westerly during the day, with speeds increasing in the afternoon as is typical for the sea breeze in this region. For a few sampling days winds were variable in both speed and direction.

\subsection{Methodology for estimating the number fraction of thickly coated particles $(f)$ in our study}

As previously mentioned, the mixing state of $\mathrm{rBC}$ can be identified using the lag-time method to bin $\mathrm{rBC}$-containing particles in two categories: (1) uncoated and thinly coated and (2) thickly coated. The lag-time method has been used in numerous studies and takes advantage of the connection between coating thickness and time delay between measured pseudo-Gaussian scattering and incandescence signal peaks for a given rBC-containing particle (Moteki et al., 2007; McMeeking et al., 2011; Metcalf et al., 2012; Wang et al., 2014; Krasowsky et al., 2016). Generally, both incandescence and scattering signals will increase as an rBCcontaining particle begins to traverse the cross section of the SP2 laser beam. However, thickly coated rBC-containing particles will have a discernable peak in scattering as the 
coating vaporizes prior to the measured peak in incandescence, which occurs when the particle reaches the center of the laser beam. This method assumes that $\mathrm{rBC}$-containing particles have a core-shell morphology and that coatings of differing species evaporate at the same rate (Metcalf et al., 2012). A small fraction of $\mathrm{rBC}$-containing particles have an incandescence signal that precedes the scattering signal due to non-core-shell structure (Sedlacek et al., 2012). Measurements of ambient air usually show a bimodal distribution of lag times where the cluster of longer (shorter) lag times corresponds to $\mathrm{rBC}$-containing particles with thicker (thinner) coatings. To stratify rBC-containing particles as thinly or thickly coated, the user selects a fixed lag-time cutoff based on this measured bimodal distribution, and particles with lag times greater than the set cutoff are binned as thickly coated. For our study, we chose a time cutoff ( $1 \mu \mathrm{s})$ based on the nearroad site and applied this to both sampling locations for consistency. We note that this cutoff is lower than that used in our previous measurements in the Los Angeles Basin using the same instrument (Krasowsky et al., 2016). After classifying each measured particle as thinly or thickly coated, we computed the number fraction of $\mathrm{rBC}$-containing particles that are thickly coated $(f)$ as the ratio of particles with lag times greater than $1 \mu$ s to the number of all $\mathrm{rBC}$-containing particles. By definition, $f$ is sensitive to the cutoff value. The cutoff defines thickly vs. thinly coated $\mathrm{BC}$ and as such $f$ is a relative metric. In general, we choose the cutoff value based on the histogram of lag times so that the data are divided based on the population of BC particles measured. To increase or decrease the lag-time cutoff would directly influence the absolute values of $f$ because it would divide up the population of particles differently. Increasing the cutoff would decrease $f$ in all cases (see Table S1 in the Supplement). This makes it difficult to compare $f$ from one study to another and provides motivation for using a method that can quantify absolute coating thickness (i.e., leading edge only). To perform the lag-time method, it is necessary to restrict the lower size limit of detection of incandescence to $170 \mathrm{~nm}$ MED (mass equivalent diameter) $\mathrm{rBC}$ cores, ensuring that the smallest possible $\mathrm{rBC}$-containing particles reported in the $f$ analysis would be detectable by the scattering channel. For this reason, reported values of $f$ represent a subset of the detectable rBC size range of the SP2. We note that an important limitation of reporting $f$ is that the metric gives insight as to whether or not thick coatings are present without attempting to quantify the coating thickness. See the Sect. S1.2 for a thorough review of past studies that have used the SP2 to determine $\mathrm{BC}$ mixing state.

\subsection{Leading-edge-only fit methodology for quantifying coating thickness on $\mathrm{rBC}$-containing particles}

Rather than stratifying particles as thinly or thickly coated, numerous studies (see Sect. 1) have employed the leadingedge-only fit method to quantify coating thickness on rBC particles. In this study, we use the Paul Scherrer Institute's single-particle soot photometer toolkit (PSI-TK) version 4.100a (originally developed by Martin Gysel with the help of Marie Laborde and others) in IGOR version 6.36 to perform the LEO method. Please see the Supplement for a detailed description of our implementation of the LEO method to quantify coating thickness. For the LEO analysis, we report coating thickness for $\mathrm{rBC}$-containing particles that have $\mathrm{rBC}$ core diameters ranging from 240 to $280 \mathrm{~nm}$.

For the measurements reported here we loaded one of every five particles into Igor Pro. The SP2 can accurately size light scattering particles (both free of as well as containing $\mathrm{rBC}$ ) down to $\sim 170 \mathrm{~nm}$ volume-equivalent diameter (VED) (Krasowsky et al., 2016). However, for the LEO analysis, care was taken to set the lower size thresholds in the PSITK to a more conservative value $(200 \mathrm{~nm})$. The more conservative limit reduces noise in LEO verification statistics by eliminating particles with size near the lower detection limit of the split detector. We note that our instrument was particularly prone to noise at lower optical diameters $(<200 \mathrm{~nm}$ VED). Though $200 \mathrm{~nm}$ VED was the minimum cutoff used from the scattering signal, we report LEO coating thickness for $\mathrm{rBC}$ cores ranging from 240 to $280 \mathrm{~nm}$. For this $\mathrm{rBC}$ core size range, coating thickness can be determined for all rBC-containing particles. Theoretically, the smallest possible rBC-containing particle included in this analysis would be a pure $\mathrm{rBC}$ particle $240 \mathrm{~nm}$ in diameter without internally mixed scattering material. The aforementioned minimum cutoff of $200 \mathrm{~nm}$ VED only applies to the LEO analyses described here; the lower threshold for other analyses presented in this study was $170 \mathrm{~nm}$. See Sect. S1.2 for a thorough review of past studies that have used the SP2 to determine $\mathrm{BC}$ mixing state.

\subsection{Estimation of photochemical age}

Photochemical age (PCA) was assessed using co-located nitrogen oxides $\left(\mathrm{NO}_{x}\right)$ and total reactive nitrogen $\left(\mathrm{NO}_{y}\right)$ measurements supplied by the SCAQMD from their Rubidoux site (500 N. Dearborn St. Redlands, CA 92374), which is approximately $30 \mathrm{~km}$ southwest (i.e., upwind, assuming typical afternoon westerly sea breezes) of Redlands. This estimate of PCA was computed using the same method described in Cappa et al. (2012) and Krasowsky et al. (2016), where $\mathrm{NO}_{x}$ is assumed to be the source of all $\mathrm{NO}_{y}$ and $\mathrm{HNO}_{3}$ is the dominant loss product of $\mathrm{NO}_{x}$. This metric is intended to give a relative estimate of the sample age by ranking measurements from least to most aged. We assume that PCA derived from measurements at Rubidoux are fairly representative of values for Redlands. Because we lacked the required $\mathrm{NO}_{x}$ and $\mathrm{NO}_{y}$ measurements at the Redlands location to perform a direct analysis of PCA at the measurement site, we also used hourly ozone mixing ratios supplied by the SCAQMD for Redlands to get a sense of photochemical air pollutant production per day. 


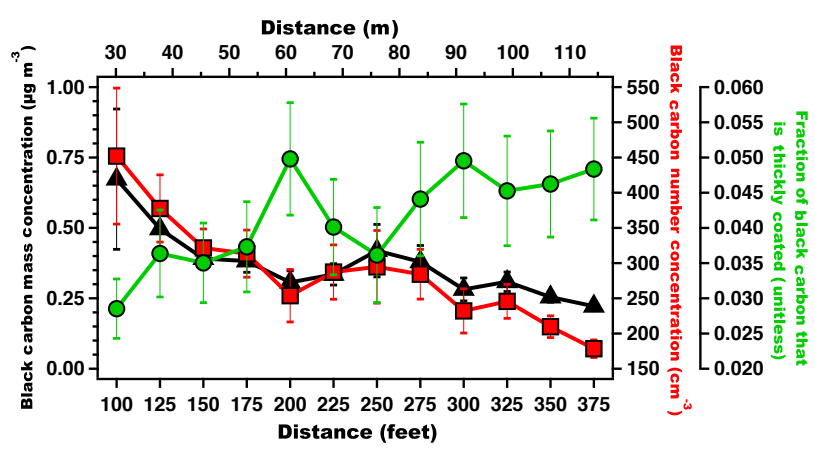

Figure 1. Black carbon mass concentration $\left(\mu \mathrm{g} \mathrm{m}^{-3}\right)$, black carbon number concentration $\left(\mathrm{cm}^{-3}\right)$, and fraction of black carbon that is thickly coated $(f)$ vs. downwind distance from Interstate 405 in Los Angeles, California. Error bars represent $95 \%$ confidence intervals computed using $10 \mathrm{~s}$ averages.

\subsection{Weekday vs. weekend analysis}

An analysis of differences in physical properties of $\mathrm{rBC}$ containing particles for weekdays vs. weekends is presented in this study for measurements at the Redlands site. (All measurements at the near-road site are for weekdays.) We define weekdays as Tuesdays through Thursdays and weekends as Sundays. This avoids confounding weekday-weekend differences by aerosols with lifetime greater than 1 day in the Los Angeles Basin. For example, measurements made on Mondays likely include a contribution of aerosols that were emitted within the basin on Sunday.

\section{Results and discussion}

\subsection{Near-road spatial trends}

\subsection{1 rBC concentrations and coated fraction}

Figure 1 shows $\mathrm{rBC}$ mass concentration, $\mathrm{rBC}$ number concentration, and $f$ vs. distance from the highway. Markers and error bars shown here represent the mean $\pm 95 \%$ confidence intervals for measurements made during the 4 sampling days in August and September. While results are not monotonic as distance from the highway increases, likely due to turbulent eddies and flow irregularities near the highway, there is an overall decrease in rBC mass concentrations as distance increases, as was similarly reported in Zhu et al. (2002). In addition, increases in distance are associated with overall decreases in $\mathrm{rBC}$ number concentrations and increases in $f$. The observed trend in $\mathrm{rBC}$ mass and number concentrations likely occur because of vehicle emissions from the highway being transported away from the source and entraining background air with lower $\mathrm{rBC}$ concentrations. Regarding $f$, we propose three possible explanations for the observed trend. The first is analogous to the driver of $\mathrm{rBC}$ mass and number concentration decreases; as distance from the highway increases, the plume dilutes and entrains background air that would likely include a greater fraction of thickly coated aged particles. Because $f$ is a relative measurement that bins particles as either thinly or thickly coated, and values of $f$ are small near the highway, entraining aged $\mathrm{rBC}$ into the highway plume could have large relative impacts on the fraction of particles that are thickly coated. A second possible explanation is that $\mathrm{rBC}$ may be acquiring coatings as it is transported away from the highway, likely dominated by condensation of condensable vapors onto $\mathrm{rBC}$, with a lower relative contribution of coagulation of externally mixed particles. Zhang et al. (2004) found that condensation led to particle growth as distance from the highway increased at the same site. A third possible explanation is that, as $\mathrm{rBC}$ mass and number concentrations decrease as distance from the highway increases, the availability of condensation sites (i.e., $\mathrm{rBC}$ particles) may decrease relative to condensable vapor concentrations, and this could lead to increased coating thicknesses. We note that the trends in BC mass and number concentrations and $f$ reported in Fig. 1 can have important implications on both human exposures to BC downwind of highways and airway deposition probabilities for BC. Reductions in $\mathrm{BC}$ mass and number concentrations would tend to reduce overall exposure to BC. However, as discussed in Sect. 1, increased coatings can raise the hygroscopicity of $\mathrm{BC}$, allowing ultrafine $\mathrm{BC}$ particles to grow into the accumulation mode in the high-relative-humidity environment of the human airways, which would tend to reduce lung deposition probability. On the other hand, coated BC may be more toxic than uncoated BC. There are interesting potential trade-offs in total exposure vs. lung deposition probability and toxicity for the high concentration environments near freeways (and potentially other source types) vs. receptor locations with lower concentrations but more aged BC.

Zhu et al. (2002) investigated ultrafine particles at the same site over a decade ago. As a part of their campaign, they measured $\mathrm{BC}$ mass concentrations using a dual-beam aethalometer (model AE-20, Andersen model RTAA-900, Andersen Instruments, Inc.) at 30, 60, 90, 150, and $300 \mathrm{~m}$ downwind and upwind of Interstate 405. We compare here our SP2 measurements of refractory black carbon made at 30,61 , and $91 \mathrm{~m}$ downwind of the highway to their measurements made 30 , 60 , and $90 \mathrm{~m}$ downwind of the highway. Relative to values at $30 \mathrm{~m}$, our study suggests that $\mathrm{rBC}$ mass concentrations at 61 and $91 \mathrm{~m}$ decrease by $54 \%$ and $58 \%$, respectively. Corresponding values for Zhu et al. (2002) are $41 \%$ and $54 \%$ (Table 2). rBC mass concentrations from our measurements were about an order of magnitude lower than the 2001 measurements. We suggest that this decrease is primarily the result of stringent and effective policy implementation aimed at curbing emissions from vehicles as has shown to be the case at locations across the Los Angeles Basin (e.g., Hasheminassab et al., 2014). However, some differences may also be attributed to variations in measurement technique. Zhu et al. (2002) used an aethalometer to measure black carbon 
Table 2. Mean rBC mass concentration for the Redlands measurement campaign, and mean rBC (and black carbon) mass concentrations corresponding to three measured distances downwind of Interstate 405 in the Los Angeles National Cemetery in 2016 (rBC from the current study) and 2001 (BC from Zhu et al., 2002).

\begin{tabular}{|c|c|c|c|}
\hline Study & Location & Time period & Mass concentration $\left(\mu \mathrm{g} \mathrm{m}^{-3}\right)$ \\
\hline \multirow[t]{3}{*}{ Zhu et al. $(2002)^{\mathrm{a}}$} & $\begin{array}{l}30 \mathrm{~m} \text { downwind of } \\
\text { Interstate } 405\end{array}$ & 15 May-18 July 2001 & $5.4(3.4-10.0)^{\mathrm{d}}$ \\
\hline & $\begin{array}{l}60 \mathrm{~m} \text { downwind of } \\
\text { Interstate } 405\end{array}$ & 15 May-18 July 2001 & $3.2(3.0-3.5)^{\mathrm{d}}$ \\
\hline & $\begin{array}{l}90 \mathrm{~m} \text { downwind of } \\
\text { Interstate } 405\end{array}$ & 15 May-18 July 2001 & $2.5(2.4-2.6)^{\mathrm{d}}$ \\
\hline \multirow[t]{4}{*}{ This studyb } & $\begin{array}{l}30 \mathrm{~m} \text { downwind of } \\
\text { Interstate } 405^{\mathrm{c}}\end{array}$ & $\begin{array}{l}4 \text { August } 2016 \\
5 \text { August } 2016 \\
12 \text { September } 2016 \\
14 \text { September } 2016\end{array}$ & 0.67 \\
\hline & $\begin{array}{l}61 \mathrm{~m} \text { downwind of } \\
\text { Interstate } 405^{\mathrm{c}}\end{array}$ & $\begin{array}{l}4 \text { August } 2016 \\
5 \text { August } 2016 \\
12 \text { September } 2016 \\
14 \text { September } 2016\end{array}$ & 0.31 \\
\hline & $\begin{array}{l}91 \mathrm{~m} \text { downwind of } \\
\text { Interstate } 405^{\mathrm{c}}\end{array}$ & $\begin{array}{l}4 \text { August } 2016 \\
5 \text { August } 2016 \\
12 \text { September } 2016 \\
14 \text { September } 2016\end{array}$ & 0.28 \\
\hline & Redlands campaign & $\begin{array}{l}16 \text { September- } \\
10 \text { October } 2016\end{array}$ & $0.14 \pm 0.10^{\mathrm{e}}$ \\
\hline
\end{tabular}

a Measurements of black carbon were made using a dual-beam aethalometer (model AE-20, Andersen model RTAA-900, Andersen Instruments Inc.). ${ }^{\mathrm{b}}$ Measurements of refractory black carbon were made using a single-particle soot photometer (Droplet Measurement Technologies, Inc.). ${ }^{c}$ Note that only 3 of the 12 measured distances from the current study are shown to allow for direct comparison to Zhu et al. (2002). ${ }^{\mathrm{d}}$ Measured average concentrations with the range given in parenthesis. ${ }^{\mathrm{e}}$ Hourly mean \pm standard deviation.

while we performed measurements of refractory black carbon using an SP2. Although the SP2 has a lower limit of detection of $70 \mathrm{~nm}$ core diameter, size distributions measured in this study at both locations suggest that the majority of total black carbon mass is from particles greater than $70 \mathrm{~nm}$ in diameter, as expected.

Figure $2 \mathrm{a}$ and $\mathrm{b}$ show $f$ vs. rBC mass and number concentrations with color coding highlighting the dependence of these variables on distance from the highway. Each point represents $10 \mathrm{~s}$ averages. The highest values of $f(\sim 0.2)$ are associated with the lowest values of $\mathrm{rBC}$ mass $\left(\sim 0.1 \mu \mathrm{g} \mathrm{m}^{-3}\right)$ and number concentrations $\left(\sim 100 \mathrm{~cm}^{-3}\right)$. Similarly, the lowest values of $f(\sim 0.01)$ are associated with the highest values of $\mathrm{rBC}$ mass $\left(\sim 0.3-1.1 \mu \mathrm{g} \mathrm{m}^{-3}\right)$ and number concentrations $\left(\sim 200-1000 \mathrm{~cm}^{-3}\right)$. rBC mass concentration and $f$ are anti-correlated with $r=-0.21$; similarly, rBC number concentration and $f$ are anti-correlated with $r=-0.25$. There appears to be a denser population of thickly coated $\mathrm{rBC}$ at distances greater than roughly $60 \mathrm{~m}$ from the highway. Given that $\mathrm{rBC}$ mass concentrations can be considered a conservative tracer, Fig. 2a shows systematic increases in $f$ as emissions from motor vehicles become increasingly diluted away from the highway. Although rBC number concentrations are theoretically not conserved due to possible coagulation of rBC-containing particles, Fig. 2b nonetheless shows systematic increases in $f$ as rBC number concentrations decrease. See the Fig. S2 in the Supplement for a box and whiskers plot that summarizes the data presented in Fig. 2.

\subsection{2 rBC size distribution}

Refractory black carbon mass and number size distributions were computed for three distances from the highway averaged over the 4 sampling days (Fig. 3a and b). We report size distributions for $\mathrm{rBC}$-containing particles with mass equivalent diameters ranging from 70 to $450 \mathrm{~nm}$, similar to previous studies (Gao et al., 2007; Moteki and Kondo, 2007; Dahlkötter et al., 2014; Krasowsky et al., 2016). Lognormal fits and their corresponding geometric means and standard deviations are also shown. Lognormal fits for each size distribution were carried out independently and without constraints. We also note that single-mode lognormal fits are insufficient for fitting data over all particle sizes, especially for the mass and number size distributions at $30 \mathrm{~m}$. rBC mass and number concentration decreased at all core diameters 

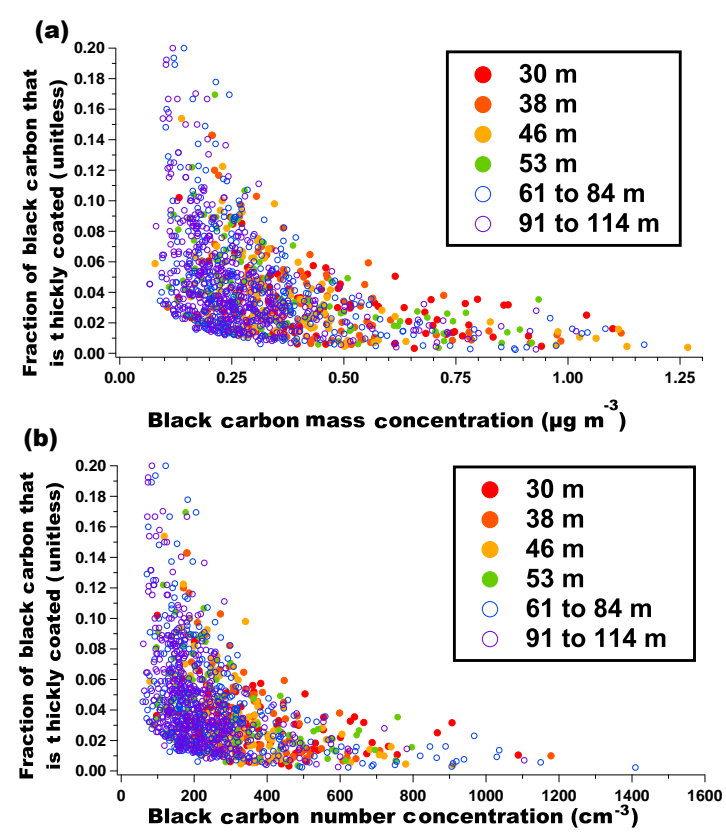

Figure 2. Fraction of black carbon that is thickly coated $(f)$ vs. (a) black carbon mass concentration $\left(\mu \mathrm{g} \mathrm{m}^{-3}\right)$ and (b) black carbon number concentration $\left(\mathrm{cm}^{-3}\right)$. Colors depict distances from Interstate 405 corresponding to the measurement location. Values on this figure have been filtered to remove $10 \mathrm{~s}$ periods with $f=0$. (a)

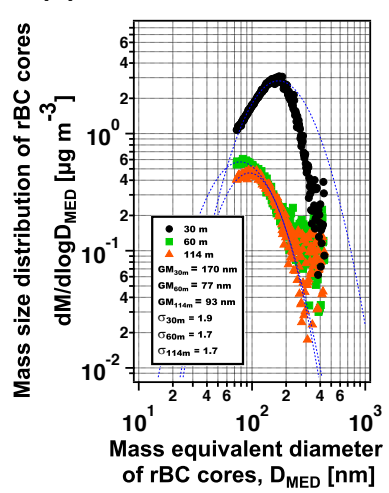

(b)

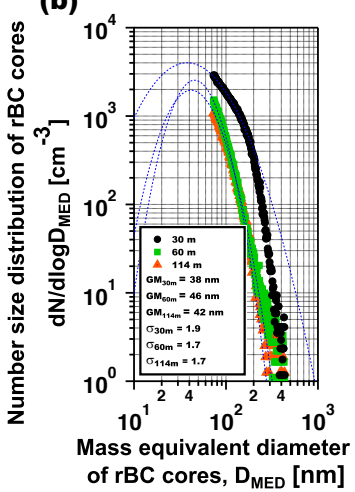

Figure 3. rBC (a) mass and (b) number size distributions. Values

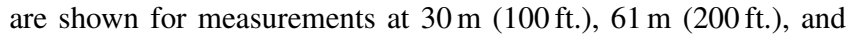
$114 \mathrm{~m}$ (375 ft.) downwind of Interstate 405 in Los Angeles, California. Lognormal fits and their corresponding geometric means (GM) and standard deviations $(\sigma)$ are shown for each distance.

measured as distance from the highway increased. Concentrations at most sizes were substantially greater nearest the highway (i.e., $30 \mathrm{~m}$ ) relative to other distances. The geometric mean diameter for the lognormal fit to the number size distribution is lower for the closest distance (i.e., $38 \mathrm{~nm}$ ) than the farther distances measured (i.e., 46 and $42 \mathrm{~nm}$ ) as expected, likely due to increased loss rates for ultrafine vs.

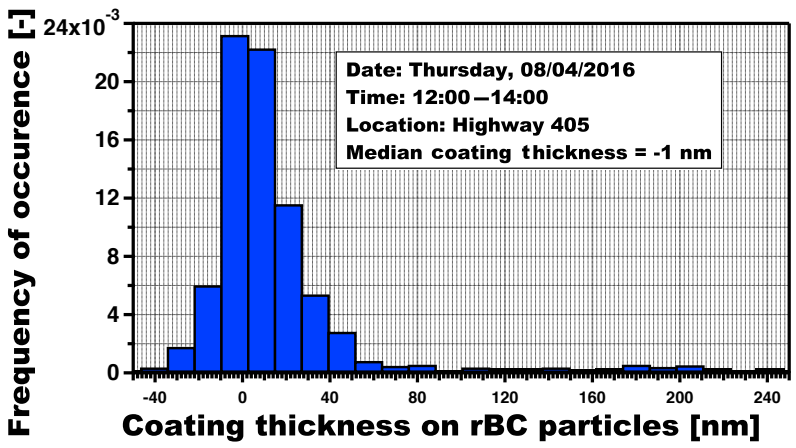

Figure 4. Coating thickness histogram for $\mathrm{rBC}$-containing particles as estimated using the leading-edge-only (LEO) method. Measurements were made at downwind distances ranging from 30 to $114 \mathrm{~m}$ (100-375 ft.) of Interstate 405 in Los Angeles on 4 August 2016.

accumulation-mode particles. Note that we cannot rule out additional peaks in the number size distribution below the lower limit of detection for $\mathrm{rBC}$ cores (i.e., $70 \mathrm{~nm}$ ), which would not be reflected in the lognormal fits. Diameters of $\mathrm{rBC}$ corresponding to peaks in the mass size distribution are $170 \mathrm{~nm}$ MED for $30 \mathrm{~m}$ from the highway, higher than values for 61 and $114 \mathrm{~m}$ of 77 and $93 \mathrm{~nm}$, respectively.

\subsubsection{Coating thickness}

In this section, we investigate coating thickness for $\mathrm{rBC}$ containing particles near the highway. Median coating thickness using the LEO method was determined for all measured distances from the highway over one of the sampling days (4 August). The histogram of coating thickness for each measured $\mathrm{rBC}$-containing particle is shown in Fig. 4. The median coating thickness was $-1 \mathrm{~nm}$ or approximately $0 \mathrm{~nm}$. While some particles with coating thickness up to $\sim 240 \mathrm{~nm}$ were measured, the majority of values range from -40 to $40 \mathrm{~nm}$. This implies that while there are some $\mathrm{rBC}$ particles with thick coatings, as can also be observed from the reported values of $f$ (Fig. 1), the majority of particles have little to no coatings. We note that it is common in past studies to have reported LEO histograms that include negative values up to about $-40 \mathrm{~nm}$ (e.g., Metcalf et al., 2012; Laborde et al., 2013) as in our study; these negative coating thicknesses are attributed to experimental uncertainty.

\subsection{Redlands campaign}

\subsubsection{Campaign overview}

Figure 5 shows an overview from 16 September to 10 October of hourly average results for the Redlands measurement campaign, including rBC mass concentration, $f$, ozone mixing ratio, and an estimate of photochemical age. The overall $\mathrm{rBC}$ mass concentration (mean \pm standard deviation) was $0.14 \pm 0.097 \mu \mathrm{g} \mathrm{m}^{-3}$. $\mathrm{rBC}$ mass concentrations reach values 


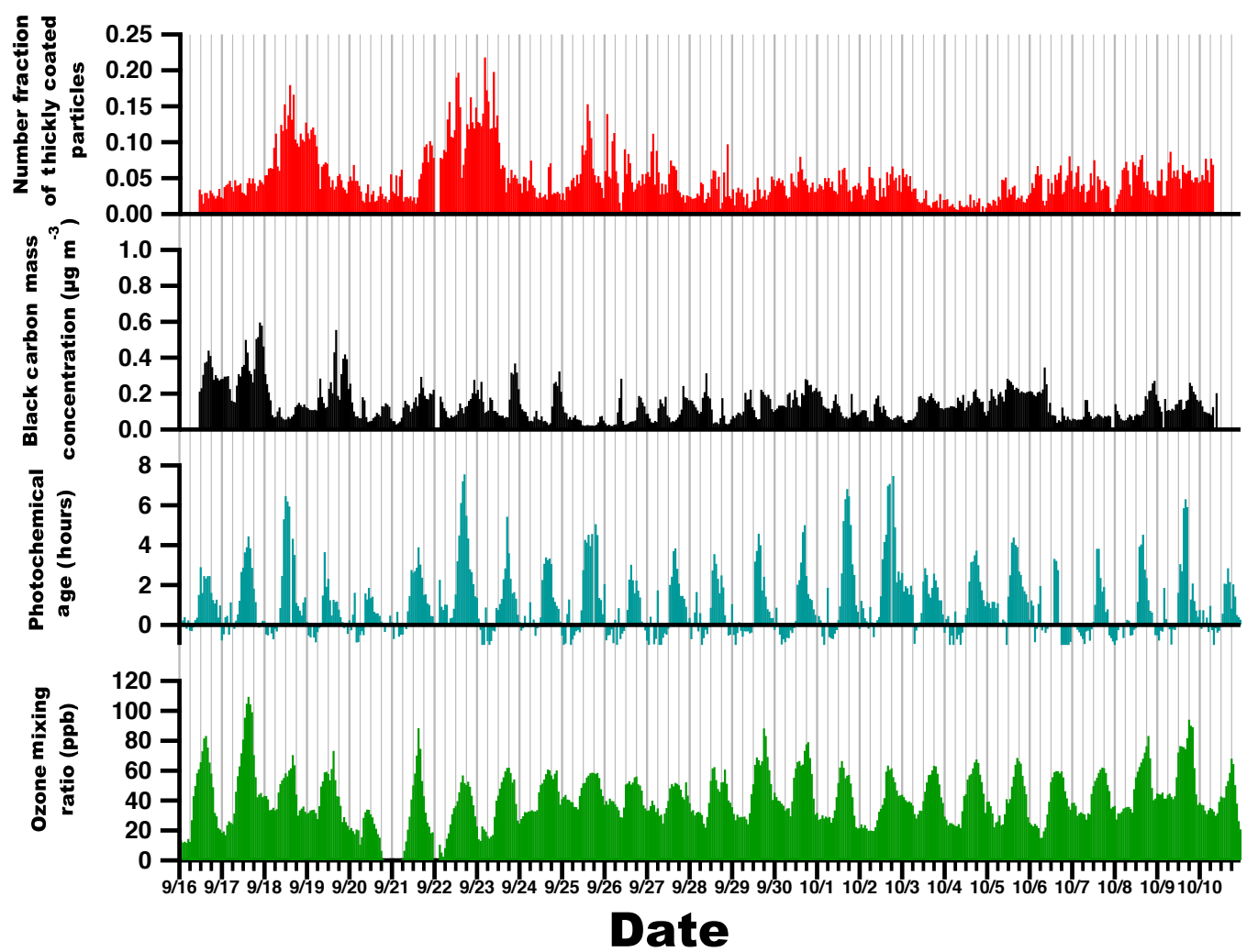

Figure 5. Overview of hourly mean results for the Redlands campaign including fraction of $\mathrm{rBC}$ that is thickly coated ( $f$, estimated using the lag-time method), $\mathrm{rBC}$ mass concentration $\left(\mu \mathrm{g} \mathrm{m}^{-3}\right.$ ), and ozone mixing ratio (ppb). Photochemical age (PCA) was computed using measurements of $\mathrm{NO}_{x}$ to $\mathrm{NO}_{y}$ at Rubidoux, California, roughly $30 \mathrm{~km}$ to the southwest of Redlands.

up to about $0.6 \mu \mathrm{g} \mathrm{m}^{-3}$. (Note that we removed from the figure an anomalously high outlier on 9 October at 03:00, which was likely due to a strong nearby source.) Values of $f$ vary by day and reach values up to about 0.2 . Values of PCA show strong diurnal variation, as expected, with daily peaks generally occurring in the early afternoon and ranging in value up to a maximum of about $7 \mathrm{~h}$. Diurnal cycles for PCA are similar in shape to those for $\mathrm{O}_{3}$, providing confidence that PCA derived from measurements in Rubidoux, California, can be used to reasonably approximate the photochemical age of air in nearby Redlands, California.

\subsubsection{Diurnal cycles of $\mathrm{rBC}$ mass concentrations and number fraction of thickly coated particles}

Campaign-average diurnal cycles of rBC mass concentrations and number fraction of thickly coated particles are shown separately for weekdays and weekends in Fig. 6a and $b$. On weekdays, the highest mass concentrations occur between 07:00 and 09:00 when commuter traffic peaks and the atmospheric mixing height is low. There is also a secondary peak in the early evening when commuter traffic increases and mixing heights start decreasing (relative to midday). $\mathrm{rBC}$ concentrations on weekends show less hour- to-hour variation during daytime than weekdays, as expected, due to more consistent traffic flows. $\mathrm{rBC}$ concentrations are higher at night than during the day due to low nocturnal mixing heights. At the $95 \%$ confidence level there were no statistically distinguishable differences between weekdays and weekends at most times of day. (Note that error bars are larger for weekends than weekdays due to the reduced weekend days sampled.) However, rBC mass concentrations were systematically higher for weekdays than weekends for all hours of the day (with the exception of the early morning hours), which may be attributed to higher diesel truck activity on weekdays vs. weekends (Marr and Harley, 2002; Lough et al., 2006). The average diurnal cycle for weekdays in this study shows less variability than our recent study (Krasowsky et al., 2016) reporting measurements in Rubidoux during winter. This is likely because (a) Rubidoux is closer to downtown Los Angeles, where a large fraction of the emissions from the Los Angeles Basin occur; and (b) atmospheric mixing heights during winter are generally lower than during summer. (Future work could investigate whether weekdayweekend differences in $\mathrm{rBC}$ are diminishing due to particulate matter regulations for trucks, but this is beyond the scope of the current study.) 

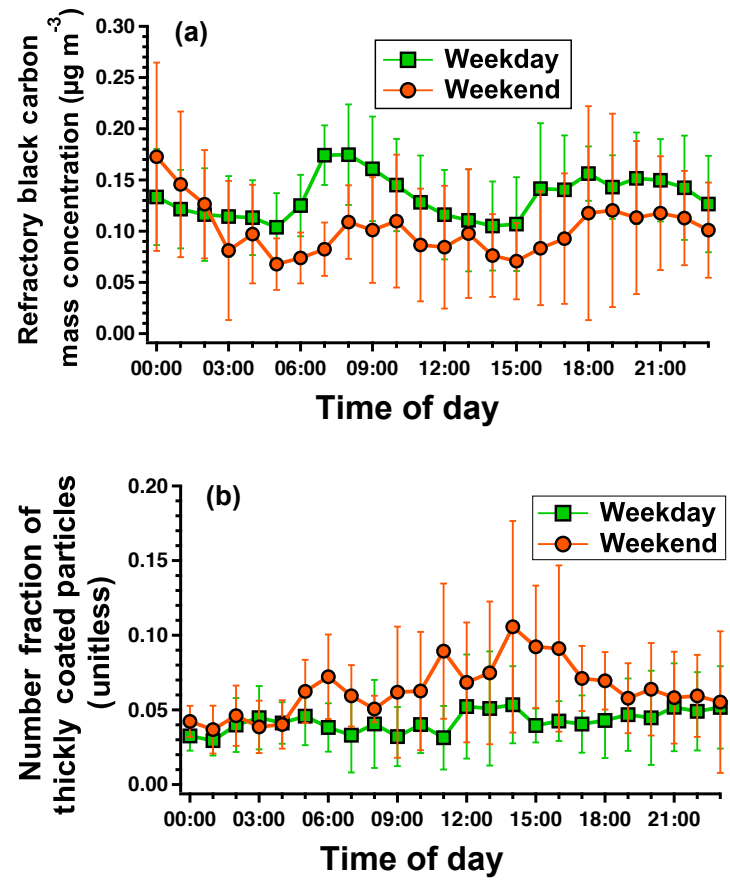

Figure 6. Mean diurnal cycle of ambient (a) black carbon mass concentration, and (b) number fraction of particles that are thickly coated $(f)$, averaged over the entire measurement campaign and shown separately for weekdays and weekends. Error bars are $95 \%$ confidence intervals using the Student's $t$ distribution and computed using day-to-day variability in each hourly average. Weekdays are defined as Tuesday through Thursday, and weekends are defined as Sundays.

Campaign-average diurnal cycles for $f$ are shown in Fig. 6b. On weekdays, values of $f$ are relatively consistent throughout the day. However, values of $f$ for weekends show a discernable peak at 14:00 when PCA and $\mathrm{O}_{3}$ (Fig. 7) values are at (or near) their diurnal peak. $f$ is systematically higher on weekends than weekdays, though differences are generally not statistically significant. Previous studies have shown that coatings on rBC in urban plumes can be sensitive to differences in the vehicle fleet for weekdays vs. weekends (Metcalf et al., 2012; Krasowsky et al., 2016). Traffic is overall lower on weekends than weekdays, but relative decreases in diesel truck traffic are larger than for light-duty vehicles. Thus, reductions in $\mathrm{NO}_{x}$ are larger than those for nonmethane volatile organic compounds (NMVOC), which due to nonlinearities in ozone chemistry can lead to higher ozone concentrations on weekends relative to weekdays. During our campaign, the weekday and weekend mean $( \pm 95 \%$ confidence interval) $\mathrm{O}_{3}$ mixing ratio at 15:00 was $60.4 \pm 13.6$ and $68.9 \pm 16.5 \mathrm{ppb}$, respectively (see Fig. 7). Since ozone can be used as a surrogate for SOA (Turpin and Huntzicker, 1991; Turpin et al., 1994; Bahreini et al., 2012; Pollack et al., 2012; Warneke et al., 2013; Heo et al., 2015), we expect that SOA concentrations would also be higher on measured

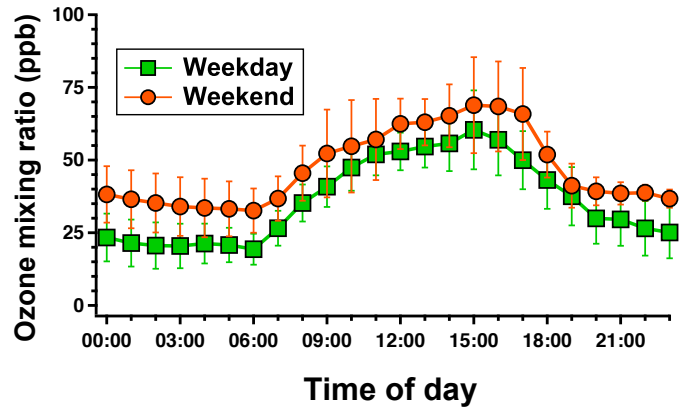

Figure 7. Mean diurnal cycles of the ozone mixing ratio (ppb) measured in Redlands, California. Weekdays and weekends are defined as in Fig. 6. Peak values occur at 15:00 and correspond to $60.4 \pm 13.6 \mathrm{ppb}( \pm 95 \%$ confidence interval) on weekdays and $68.9 \pm 16.5 \mathrm{ppb}$ on weekends.

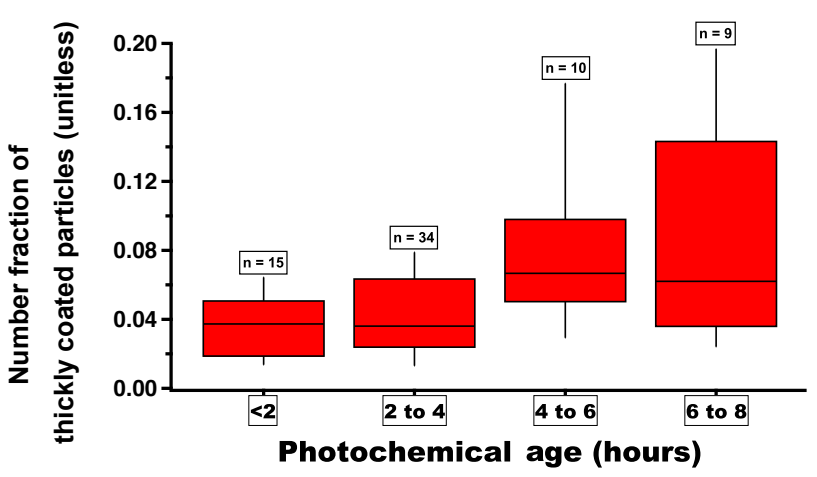

Figure 8. Number fraction of $\mathrm{rBC}$ particles that are thickly coated $(f)$ vs. photochemical age (PCA) for the hours of 13:00 to 16:00. Boxes depict the 25th and 75th percentiles, whiskers depict the 10th and 90th percentile, and the horizontal lines within the boxes show the median. The text boxes indicate the number of data points in each bin.

weekends than weekdays. Thus, we hypothesize that condensation of SOA onto reduced available $\mathrm{rBC}$ condensation sites could be one important physiochemical process describing the systematically higher values of $f$ on weekends in Fig. 6b.

\subsubsection{Number fraction of thickly coated particles vs. photochemical age}

Figure 8 shows the number fraction of $\mathrm{rBC}$-containing particles that are thickly coated vs. photochemical age, using hourly average values between the hours of 13:00 and 16:00. Boxes depict the 25th and 75th percentiles, whiskers depict the 10th and 90th percentiles, and the horizontal lines within the boxes show the median. Only afternoon values were included to highlight coatings that likely result from photochemistry. As the photochemical age of the measured air increases, so does the fraction of particles that are thickly coated. For PCA $<2 \mathrm{~h}$, the median, 25th, and 75 th per- 
centiles for $f$ are about $0.04,0.02$, and 0.05 , respectively. For PCA values ranging from 6 to $8 \mathrm{~h}$, corresponding values for $f$ are about $0.06,0.04$, and 0.14 . Krasowsky et al. (2016) performed a similar analysis comparing $f$ vs. PCA, but results were for wintertime measurements in Rubidoux and included $f$ for all hours of the day. The previous study also used a greater lag-time cutoff of $3 \mu$ s. Both studies show increases in $f$ as PCA increases, though the previous study shows slightly higher median values for $f$ at the highest PCA bin even though the lag-time cutoff is higher. The 90th percentiles of $f$ for the highest PCA bin are quite similar for both studies. Nonetheless, the two studies are not directly comparable given the (a) difference in lag-time cutoffs used to define thickly coated $\mathrm{rBC}$ particles and (b) the difference in time of day analyzed. Evaluating the entire daily cycle as in Krasowsky et al. (2016) could confound results by including the nighttime hours where condensation of semi-volatile species and aqueous-phase chemistry may have an influence on $f$ values, while photochemistry is not directly leading to coating development (Venkatachari et al., 2005; Lim et al., 2010; Ervens et al., 2011; Hersey et al., 2011; Krasowsky et al., 2016). Note that, since we are reporting correlations between different observations, we cannot rule out the possibility that trends in $f$ vs. PCA (Fig. 8) are partially caused by other mechanisms (in addition to photochemistry) that temporally covary with photochemistry. We note that $\mathrm{NO}_{x}$ and $\mathrm{NO}_{y}$ data supplied by SCAQMD used to estimate PCA were hourly, and thus boxes and whiskers summarize hourly values.

\subsubsection{Number fraction of thickly coated particles during consistent onshore (westerly) wind episodes}

The mean number fraction of thickly coated $\mathrm{rBC}$ particles in Redlands for 13:00 to 16:00 was calculated for times when wind flows were westerly and, therefore, consistent with typical sea breeze conditions. This allows us to compare $f$ near a major source (i.e., the highway, Sect. 3.1) to that after being advected to the east side of the basin while removing confounding conditions where winds blow presumably more aged aerosols from the east. Values of $f$ were filtered to include only afternoons with hourly wind directions in the range of 225 to $315^{\circ}$. The entire afternoon was removed if any given hour had a wind direction outside of this range. Sixteen afternoons were included in the average after this conditional sampling. The mean $f$ ( \pm standard deviation) was found to be $0.055 \pm 0.041$. This is remarkably similar to $f$ values at the furthest distance from the freeway (Fig. 1). It is also similar to the $f$ value for the trend line at the lowest BC concentrations shown in Fig. 2a, which using BC mass as a tracer would indicate when the measurements were most diluted and thus most aged near the freeway.

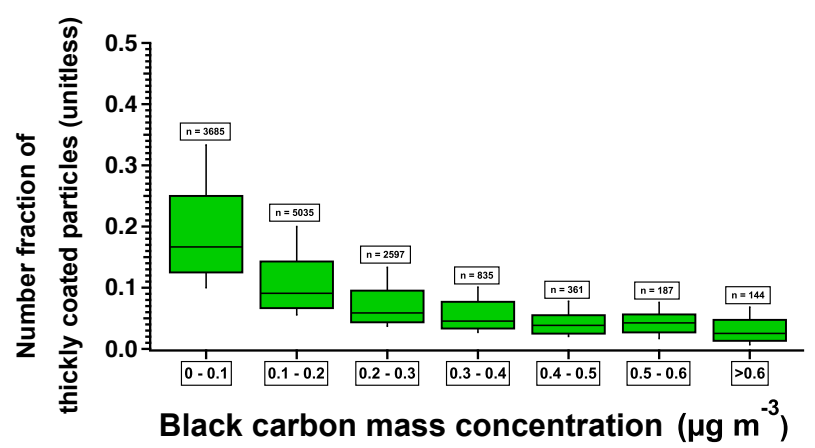

Figure 9. Number fraction of $\mathrm{rBC}$ that is thickly coated vs. $\mathrm{rBC}$ mass concentration $\left(\mu \mathrm{g} \mathrm{m}^{-3}\right)$ for measurements made in Redlands, California. Boxes and whiskers summarize data at $1 \mathrm{~min}$ resolution. Boxes depict the 25th and 75th percentiles, whiskers depict the 10th and 90th percentiles, and the horizontal lines within the boxes show the median. The text boxes indicate the number of data points in each bin. Number fraction of $\mathrm{rBC}$ that is thickly coated and $\mathrm{rBC}$ mass concentration are anti-correlated with correlation coefficient $r=-0.48$.

\subsection{5 rBC mass concentration vs. number fraction of thickly coated particles}

Figure 9 shows number fraction of $\mathrm{rBC}$ particles that are thickly coated vs. rBC mass concentration. Unlike Fig. 8, which summarizes hourly averages, Fig. 9 shows 1 min values. This higher temporal resolution allows for observing short periods with higher values of $f$ (i.e., $>0.3$ ) relative to hourly averages. Median values of $f$ are found to decrease as $\mathrm{rBC}$ mass concentration increases. For rBC mass concentrations ranging from 0 to $0.1 \mu \mathrm{g} \mathrm{m}^{-3}$, the median $f$ is 0.17 , while $\mathrm{rBC}$ mass concentrations that are greater than $0.6 \mu \mathrm{g} \mathrm{m}^{-3}$ are associated with lower median values of $f(0.03)$. Overall, $f$ and $\mathrm{rBC}$ mass concentrations are anticorrelated with correlation coefficient $r=-0.48$. As sampled air becomes more aged, $\mathrm{rBC}$ concentrations in general are expected to decrease primarily due to dilution, while $f$ would be expected to increase. In addition, the "weekend effect" discussed in the previous section is represented in this figure; weekend values show lower rBC mass concentrations and higher $f$ (Fig. 7).

\subsection{6 rBC size distributions and mixing state analysis using LEO fit for 4 days}

We conducted more in-depth analysis of the physical properties and mixing state of $\mathrm{rBC}$-containing particles for four afternoons (15:00-16:00) for the Redlands campaign. Days were chosen to sample over a variety of meteorological conditions (e.g., wind speed, wind direction, ambient temperature), as well as both weekdays and weekends. Thus, the days were chosen to include atypical meteorology for the Los Angeles Basin. For the four afternoons chosen, the National 


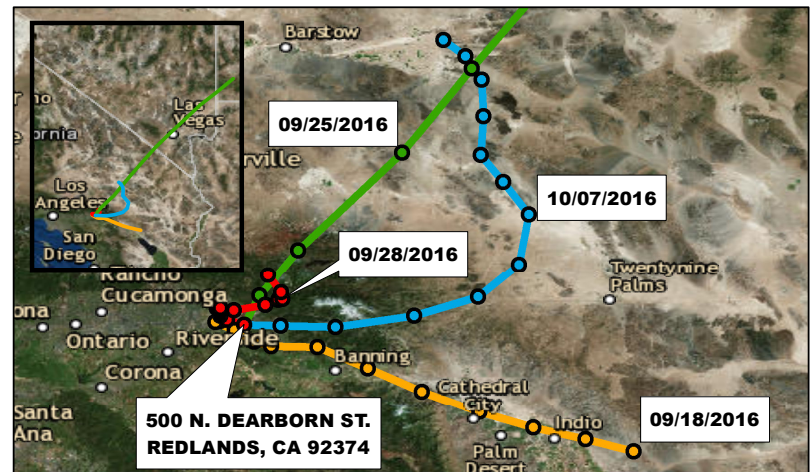

Figure 10. $12 \mathrm{~h}$ back trajectories (each black circle represents $1 \mathrm{~h}$ ) starting at 15:00 local time computed using the HYSPLIT model for 2 weekdays (28 September and 7 October) and 2 Sundays (18 and 25 September). Meteorological variables at 15:00-16:00 and rBC physical properties are in Fig. 11.

Oceanic and Atmospheric Administration's HYbrid SingleParticle Lagrangian Integrated Trajectory (HYSPLIT) model (Draxler and Hess, 1998) was employed to assess $12 \mathrm{~h}$ back trajectories starting at 15:00 on each day (Fig. 10). Properties quantified include coating thickness distributions using LEO fit and $\mathrm{rBC}$ number and mass particle size distributions.

The first afternoon examined was Sunday, 18 September (Fig. 11a, b). During 15:00-16:00 winds were westerly at $2.7 \mathrm{~m} \mathrm{~s}^{-1}$, and the daily maximum temperature was very high $\left(40.6^{\circ} \mathrm{C}\right)$. Back trajectories suggest that sampled air included contributions from both nearby regions to the west of Redlands and "low desert" regions to the east including the city of Palm Desert. The median coating thickness was $14 \mathrm{~nm}$, and a few relatively high coating thickness bins (e.g., centered at $130 \mathrm{~nm}$ ) show local peaks. $\mathrm{rBC}$ mass concentrations on this day were typical of campaign-average weekend values at this time of day (see Fig. 6a). The rBC mass size distribution shows a peak at core size of $129 \mathrm{~nm}$ MED, while the number size distribution indicates that its peak was at particle sizes smaller than the lower limit of detection $(70 \mathrm{~nm})$. The geometric mean diameter for the lognormal fit to the number distribution was $37 \mathrm{~nm}$.

We examined another Sunday, 25 September (Fig. 11c, d), with noticeably different atmospheric flow patterns (Fig. 10). During 15:00-16:00, winds were from the south at $1.8 \mathrm{~m} \mathrm{~s}^{-1}$. Back trajectories indicate that sampled air largely originated from the desert regions to the northeast as far away as Las Vegas, NV. On this day, the median coating thickness was $24 \mathrm{~nm}$. Compared to Sunday, 18 September, several coating thickness bins above $80 \mathrm{~nm}$ show higher frequencies of occurrence. $\mathrm{rBC}$ mass concentration was very low $\left(0.02 \pm 0.01 \mu \mathrm{g} \mathrm{m}^{-3}\right)$, below the campaign-average weekend value shown in Fig. 6a. Particle size distributions indicate that all sizes of $\mathrm{rBC}$ were at lower concentrations relative to 18 September, though the $\mathrm{rBC}$ core size associated with the peak in mass size distribution was similar on both days. Differences in computed back trajectories, relatively lower rBC mass concentrations, and relatively higher amounts of $\mathrm{rBC}$ with thick coatings all suggest that a higher fraction of measured rBC came from farther away sources and was increasingly aged compared to 18 September. Lower ambient temperatures on 25 September may have also played a role by favoring partitioning of semi-volatile species to the particle phase, though we have no way of determining the relative contribution of this effect.

The remaining 2 days under investigation were weekdays. Wednesday, 28 September (Fig. 11e, f), had slower and more irregular winds and cooler temperatures relative to the Sundays already discussed. Back trajectories indicate that sampled air originated from relatively close to Redlands compared to the other days (Fig. 10), which is consistent with the observed low wind speeds. The median coating thickness was $8 \mathrm{~nm}$, lower than the Sundays already discussed. The $\mathrm{rBC}$ mass concentration was $0.04 \pm 0.01 \mu \mathrm{g} \mathrm{m}^{-3}$, higher than Sunday, 25 September, but lower than Sunday, 18 September. Number size distributions for this day are quite similar to those for 18 September; however, mass size distributions on 28 September show lower concentrations at most sizes relative to 18 September, and the size of $\mathrm{rBC}$ associated with the peak mass concentration is shifted toward a smaller mass equivalent diameter (i.e., $102 \mathrm{~nm}$ ). Given the differences in back trajectories, coating thickness histograms, size distributions, and the fact that this was a weekday with higher black carbon emission rates in the Los Angeles Basin than for weekends, we conclude that the measured population of rBC may have been dominated by particles that were emitted by nearby sources and did not have sufficient time to acquire thick coatings.

The last day of interest was Friday, 7 October (Fig. 11g, h), with winds from the northwest at $1.3 \mathrm{~m} \mathrm{~s}^{-1}$ from 15:00 to 16:00 and the same daily maximum temperature as the other weekday under investigation here. Back trajectories indicate that sampled air largely came from the "high desert" region of southern California including the Barstow area (Fig. 10). Interestingly, of the 4 days discussed in this section, $\mathrm{rBC}$ sampled on this afternoon had the smallest median coating thickness $(3 \mathrm{~nm})$ and the least discernable peaks for coating thickness $>80 \mathrm{~nm}$. rBC mass concentrations were higher than other days investigated in this section, presumably due to both higher weekday emissions in the Los Angeles Basin and distinct atmospheric flow patterns for this day. We cannot isolate individual factors that contributed to the low coating thicknesses measured on this afternoon. However, we suggest that important contributors may include the fact that (a) this was a weekday and (b) back trajectories indicate that sampled air came from regions with low source emissions rates, suggesting that measured $\mathrm{rBC}$ was dominated by relatively fresh emissions from nearby sources. 
(a)

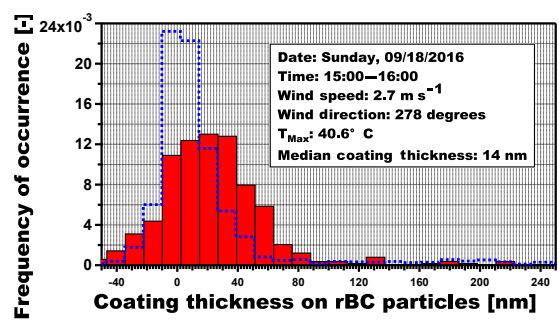

(c)

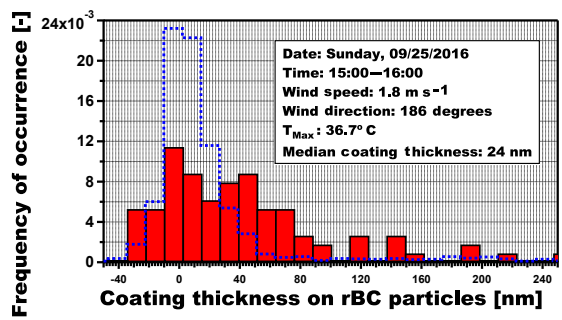

(b)

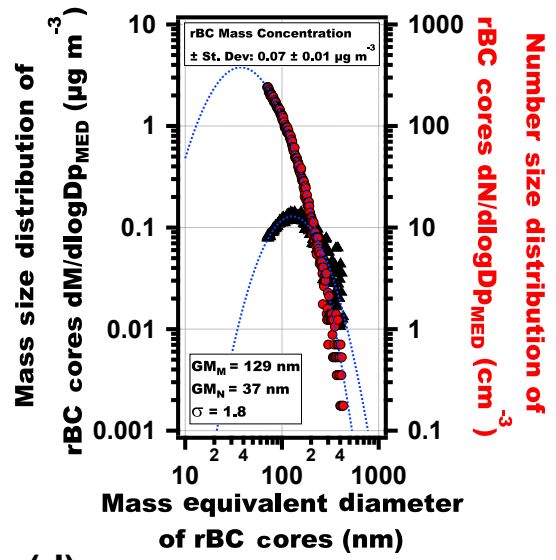

(d)

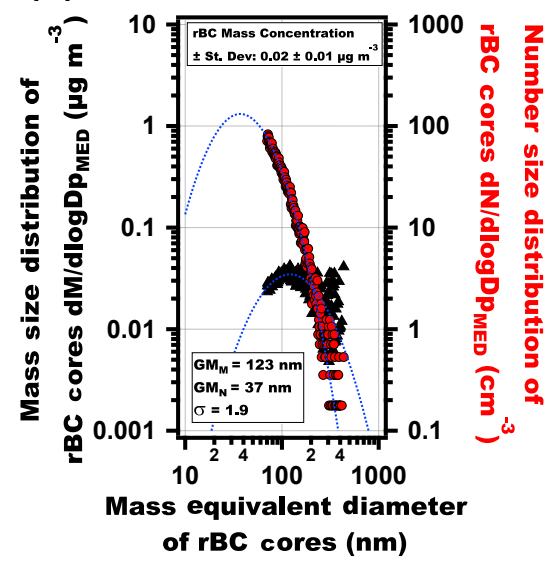

Figure 11.

\subsection{Comparison of near-road and Redlands campaigns}

We have evaluated the physical properties of $\mathrm{rBC}$ at (a) different distances from a major highway on the west side of Los Angeles and (b) the east side of the Los Angeles Basin where secondary pollutant (e.g., ozone) concentrations are among the highest observed in the basin (Hersey et al., 2011).

$\mathrm{rBC}$ mass concentrations at $30 \mathrm{~m}$ from the highway were about a factor of 3.0 higher than those measured $114 \mathrm{~m}$ from the highway. rBC mass concentrations $114 \mathrm{~m}$ from the highway were quite similar to campaign-average values for midday on weekdays in Redlands.

Particle number size distributions for $\mathrm{rBC}$ indicate that the smallest measured sizes $(\sim 70-100 \mathrm{~nm}$ mass equivalent diameter), which dominate total rBC number concentrations, decreased by a factor of about 2.7 from 30 to $114 \mathrm{~m}$ from the highway. Interestingly, rBC number concentrations for the smallest measured diameters showed values that were about an order of magnitude higher at $114 \mathrm{~m}$ from the highway relative to those measured in Redlands (i.e., compare Figs. 3a-11). Thus, rBC number concentrations were significantly higher at all near-highway distances measured relative to Redlands, while rBC mass concentrations were quite similar at Redlands vs. $114 \mathrm{~m}$ from the highway at the near-road site.

Assessing the number fraction of $\mathrm{rBC}$ that was thickly coated indicates that, while $f$ increased as the measurement location moved from 30 to $114 \mathrm{~m}$ from the highway, values observed $114 \mathrm{~m}$ from the highway were roughly similar to the median for Redlands at PCA values of 6 to $8 \mathrm{~h}$ (Fig. 1 vs. 8). We also compared $f$ values for the near-road environment to that for Redlands including only typical onshore westerly sea breeze conditions (i.e., filtering out afternoons when wind direction was not consistent with typical onshore flows). This analysis corroborated the finding that $\mathrm{BC}$ rapidly approaches $f$ values at the near-road site that are found in the broader urban plume on the east side of the Los Angeles Basin. This suggests that the typical timescales for advection of pollutants across the Los Angeles Basin may not be sufficient for $\mathrm{BC}$ to acquire coatings that are detectable using the lag-time method. More thickly coated particles can be observed under atypical meteorological conditions when winds bring more aged $\mathrm{BC}$ into the basin from the east. As indicated by the 
(e)

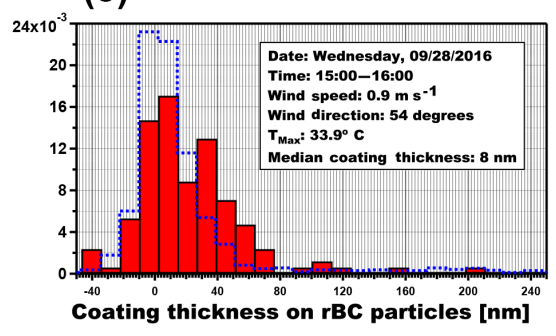

(g)

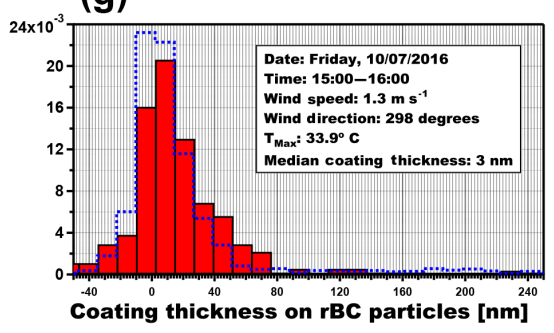

(f)

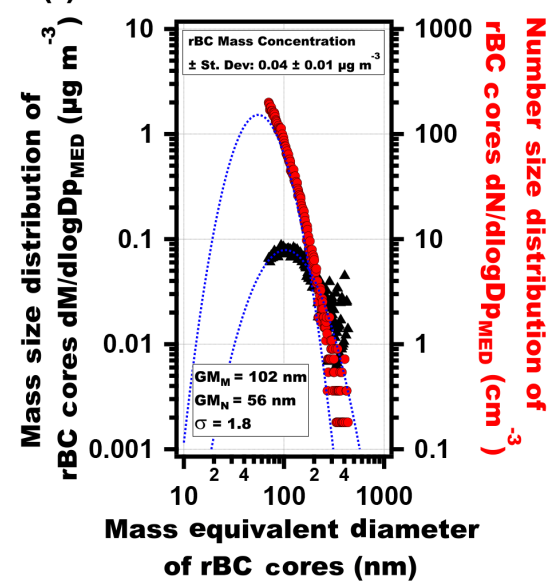

(h)

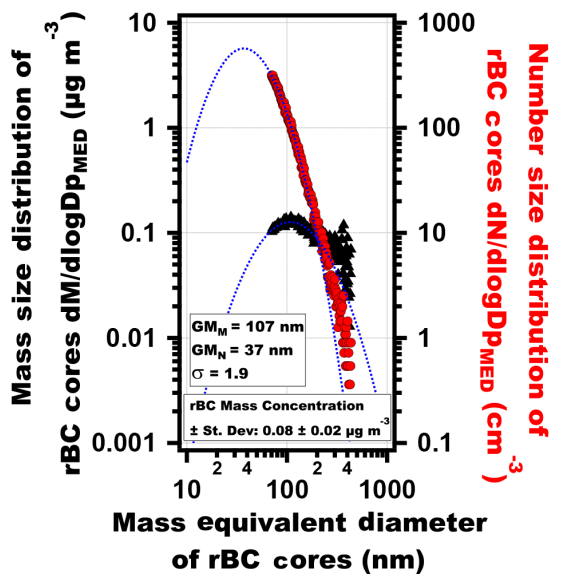

Figure 11. Coatings thickness histograms (a, c, e, g) and rBC number and mass size distributions (b, d, f, h) for 2 Sundays (a-d) and 2 weekdays (e-h) averaged for 15:00-16:00 in Redlands. Also shown in the insets are meteorological variables and median coating thicknesses $(\mathbf{a}, \mathbf{c}, \mathbf{e}, \mathbf{g})$ and $\mathrm{rBC}$ mass concentrations $(\mathbf{b}, \mathbf{d}, \mathbf{f}, \mathbf{h})$ for each of the four afternoons. Note that corresponding back trajectories are shown in Fig. 10. Coating thickness histograms in red are for Redlands and the near-road histogram (equivalent to that shown in Fig. 4) is shown with blue dashed outlines. Lognormal fits and their corresponding geometric means (GM) and standard deviations ( $\sigma$ ) are shown for each $\mathrm{rBC}$ size distribution.

boxes and whiskers in Fig. 8, there were hourly time periods during the sampling campaign where $f$ reached nearly 0.20 in Redlands and shorter time periods where $f$ reached values greater than 0.30 (Fig. 9).

Assessing coating thickness histograms suggests that most measured $\mathrm{rBC}$ was uncoated or thinly coated near the highway. Measurements in Redlands showed relatively more rBC with coating thickness $>80 \mathrm{~nm}$ under certain atmospheric conditions. This occurred especially when atmospheric flows favored $\mathrm{rBC}$ being transported from the east on weekends, which may have caused $\mathrm{rBC}$ emissions from nearby traffic sources to be lower and the relative contribution of more remote sources to be higher. (Fig. 11 shows coating thickness histograms for both Redlands and near-road sites.)

\subsection{Comparison to past studies}

Moteki et al. (2007) performed the lag-time method and found the number fraction of thickly coated particles to range from 0.35 to 0.63 for airborne measurements of $\mathrm{rBC}$ over the ocean near the coast of Japan. Wang et al. (2014) performed the lag-time method and found the number fraction of thickly coated $\mathrm{rBC}$ particles to be $0.474 \pm 0.076$ (mean \pm standard deviation) in a heavily polluted area of China. Both of these studies measured $\mathrm{rBC}$ with substantially larger fraction of thickly coated rBC than Krasowsky et al. (2016) found in urban Los Angeles, where the number fraction of thickly coated particles ranged from 0 to 0.21 with a campaign average of (mean \pm standard deviation) $0.05 \pm 0.02$. Results presented in the current study for Redlands are roughly consistent with that reported by Krasowsky et al. (2016). McMeek- 
ing et al. (2011) found comparable results to Krasowsky et al. (2016) where the number fraction of thickly coated particles was between 0.10 and 0.20 in urban areas of the United Kingdom. Metcalf et al. (2012) investigated rBC mixing state as part of CalNex and found the number fraction of thickly coated rBC particles in the Los Angeles Basin to be $0.37 \pm 0.11$ (mean \pm standard deviation). It is interesting to note that the studies that performed measurements using an aircraft (i.e., Moteki et al., 2007, and Metcalf et al., 2012) reported values of $f$ greater than 0.35 , whereas the studies using ground observations (i.e., McMeeking et al., 2011, Krasowsky et al., 2016, current study) report lower values of $f$. We suggest there may be interesting distinctions in the measured population of aerosols for campaigns using aircraft vs. ground measurements. The latter is likely to include a relatively greater contribution from locally emitted aerosols when measurements are made within an urban region even if downwind of the region with the highest emissions.

While we have provided a comparison of these past studies, it should also be noted that $f$ is by definition a metric that is dependent on the user-selected lag time. Even if two studies report similar values of $f$, thickly coated as described by this metric could mean different things for those two studies. The metric compares one mode of BC with more coating material to another mode with less coating material so can mean different things depending on the population of aerosols sampled. Some of the limitations of $f$ are ameliorated by the leading-edge-only method (Gao et al., 2007), which was developed to provide a more quantitative assessment of coating thickness. One of the novel contributions of this study is the comparison of $f$ values near a major freeway to those in Redlands using a consistent measurement system and lagtime cutoff, which allows for systematic observations of how the fraction of $\mathrm{rBC}$ evolves in time and space.

\section{Summary and conclusions}

Improving understanding in spatiotemporal distributions of refractory black carbon, as well as evolution of $\mathrm{rBC}$ physical properties and mixing state at both (a) rapid timescales near sources (e.g., road-to-ambient processing) and (b) longer timescales as pollutants are transported on urban, continental, and global scales is critical for reducing uncertainty on the impacts of aerosols on human health and regional and global climate. This study carries out measurements of ambient particles containing refractory black carbon in two distinct locations during the hottest months in southern California to systematically evaluate differences in $\mathrm{rBC}$ physical properties and mixing state near a highway and downwind of urban Los Angeles. The results reported here attempt to highlight the influence of road-to-ambient processing, varying meteorological regimes, and changing vehicle fleets on the physical properties and mixing state of rBC. Two techniques for quantifying coatings on $\mathrm{rBC}$ particles (i.e., the lag-time and LEO method) were employed using measurements made with a single-particle soot photometer (SP2). Sampling for the first location was completed near Interstate 405 at the Los Angeles National Cemetery between 12:00 and 14:00 local time on 4 August, 5 August, 12 September, and 14 September 2016. Measurements were made in $\sim 8 \mathrm{~m}$ increments from 30 to $114 \mathrm{~m}$ downwind of the highway using a mobile platform. As distance from the highway increased, $\mathrm{rBC}$ mass concentrations decreased. A previous study (Zhu et al., 2002) that measured BC with an aethalometer in 2001 at the same site reported similar trends with respect to distance from the freeway, though concentrations reported here are about an order of magnitude lower than the values reported in the previous study. This highlights the efficacy of stringent policies for reducing black carbon emissions in California though differences in measurement technique between the two studies could have also contributed. rBC number concentrations decreased, while the number fraction of thickly coated rBC particles $(f)$ showed an overall increase, as distance from the highway increased from 30 to $114 \mathrm{~m}$. rBC mass concentrations were overall anti-correlated with $f$ at this measurement site; assuming rBC mass as a conservative tracer, this trend in $f$ suggests that the fraction of thickly coated $\mathrm{rBC}$-containing particles increased as the plume from the highway diluted. On 4 August 2016, the LEO method was used to quantify coating thickness histograms; the median coating thickness for $\mathrm{rBC}$-containing particles at all distances measured was about $0 \mathrm{~nm}$. While $f$ indicated that a small fraction of rBC-containing particles (i.e., $5 \%$ ) acquired coatings as downwind distances approached $\sim 100 \mathrm{~m}$ away from the highway, most particles were essentially uncoated or thinly coated, as defined by the lag-time method.

Sampling for the second location was completed in Redlands, California, approximately $100 \mathrm{~km}$ east of downtown Los Angeles, from 16 September to 10 October 2016. The overall $\mathrm{rBC}$ mass concentration ( \pm standard deviation) was $0.14 \pm 0.097 \mu \mathrm{g} \mathrm{m}^{-3}$. Campaign-average diurnal cycles of rBC mass concentration and $f$ were analyzed separately for weekdays and weekends. During daytime, hourly values of $\mathrm{rBC}$ mass concentrations were larger on weekdays than weekends, likely due to increased diesel truck traffic on weekdays, though differences were not statistically distinguishable at the $95 \%$ confidence level. There was less hour-to-hour variation in $\mathrm{rBC}$ mass concentrations on weekends relative to weekdays presumably due to more consistent traffic flows throughout the day and less defined rush-hour periods. Values of $f$ were systematically higher on weekends than weekdays, with the peak value occurring at 14:00 when photochemistry is prevalent. We suggest that the higher weekend values in $f$ could be analogous to the ozone weekend effect but in this case would apply to higher secondary organic aerosol loadings that have the potential to condense onto reduced available $\mathrm{rBC}$, leading to more thickly coated refractory black carbon particles. Previous research by Metcalf et al. (2012) and Krasowsky et al. (2016) corroborate this 
theory. We also investigated $f$ as a function of photochemical age (PCA) for the hours of 13:00-16:00 and found that $f$ increased as PCA increased. Similar to the near-road site, $f$ was anti-correlated with rBC mass concentrations.

An examination on how various meteorological regimes impact the physical properties and mixing state of rBCcontaining particles in Redlands was completed for four afternoons ( 2 weekdays and 2 weekend days at 15:00-16:00) using $12 \mathrm{~h}$ back trajectories computed with the HYSPLIT model. We found that the afternoon with the most prevalent mode of thickly coated rBC corresponded to a Sunday with back trajectories indicating that measurements were dominated by air originating from the desert regions to the northeast of the Los Angeles Basin. Relatively lower weekend emissions from diesel truck traffic in the Los Angeles Basin and transport of air from the northeast suggest that measured rBC may have contained a larger contribution of aged particles emitted from remote locations than the other days under investigation.

Comparing rBC at the near-road site vs. Redlands shows remarkable similarity in some properties and divergence in others. At the furthest measured downwind distance (114 m) from Interstate 405, rBC mass concentrations were similar to campaign-average values for midday on weekdays in Redlands, California. On the other hand, the rBC number concentrations near the highway for the smallest size range measured (70-100 nm MED) were about an order of magnitude higher than for Redlands. While values of $f$ increased as distance from the highway increased, the observed values of $f$ at $114 \mathrm{~m}$ from the roadway were about the same as median $f$ values measured in Redlands when photochemistry was most prevalent. This suggests that the residence time of air in the Los Angeles Basin under typical conditions measured during this campaign may not be sufficient for $\mathrm{rBC}$ to acquire thick coatings. However, under certain meteorological conditions, $f$ was observed to be $\sim 0.20$, with coating thickness histograms showing a larger contribution of rBC particles with coating thickness $>80 \mathrm{~nm}$. This occurred during a weekend day when local emissions from diesel vehicles were lower (compared to weekdays) and winds brought air from the desert regions to the northeast of Los Angeles, both of which increase the relative contribution of remote sources of rBC.

Data availability. Processed data used to make figures may be available from the corresponding author. Due to the extremely large file sizes for the particle-by-particle data acquired by the SP2, raw data are not publically available.

Supplement. The supplement related to this article is available online at: https://doi.org/10.5194/acp-18-11991-2018-supplement.
Author contributions. Authors TK and GBW designed the study. TK performed the field measurements. TK and GBW carried out the data analysis. TK and GBW wrote the paper. CS and GM provided technical guidance on field measurements and data analysis and edited the paper.

Competing interests. The authors declare that they have no conflict of interest.

Acknowledgements. We thank Eyuphan Koc for his technical expertise and Cole Meyers, Theresa Berkovich, and Anders Hasselquist for their help with field measurements.

Edited by: Radovan Krejci

Reviewed by: four anonymous referees

\section{References}

Anselm, A., Heibel, T., Gebhart, J., and Ferron, G.: "In vivo" studies of growth factors of sodium chloride particles in the human respiratory tract, J. Aerosol Sci., 21, 427-430, 1990.

Bahreini, R., Middlebrook, A. M., Gouw, J. D., Warneke, C., Trainer, M., Brock, C. A., Stark, H., Brown, S. S., Dube, W. P., Gilman, J. B., and Hall, K.: Gasoline emissions dominate over diesel in formation of secondary organic aerosol mass, Geophys Res. Lett., 39, L06805, https://doi.org/10.1029/2011GL050718, 2012.

Ban-Weiss, G. A., Cao, L., Bala, G., and Caldeira, K.: Dependence of climate forcing and response on the altitude of black carbon aerosols, Clim. Dynam., 38, 897-911, https://doi.org/10.1007/s00382-011-1052-y, 2012.

Bond, T. C., Doherty, S. J., Fahey, D. W., Forster, P. M., Berntsen, T., DeAngelo, B. J., Flanner, M. G., Ghan, S., Kärcher, B., Koch, D., Kinne, S., Kondo, Y., Quinn, P. K., Sarofim, M. C., Schultz, M. G., Schulz, M., Venkataraman, C., Zhang, H., Zhang, S., Bellouin, N., Guttikunda, S. K., Hopke, P. K., Jacobson, M. Z., Kaiser, J. W., Klimont, Z., Lohmann, U., Schwarz, J. P., Shindell, D., Storelvmo, T., Warrent, S. G., and Zender, C. S.: Bounding the role of black carbon in the climate system: A scientific assessment, J. Geophys. Res., 118, 5380-5552, 2013.

Cappa, C. D., Onasch, T. B., Massoli, P., Worsnop, D., Bates, T. S., Cross, E., Davidovits, P., Hakala, J., Hayden, K., Jobson, B. T., Kolesar, K. R., Lack, D. A., Lerner, B., Li, S. M., Mellon, D., Nuaanman, I., Olfert, J., Petaja, T., Quinn, P. K., Song, C., Subramanian, R., Williams, E. J., and Zaveri, R. A.: Radiative Absorption Enhancements Due to the Mixing State of Atmospheric Black Carbon, Science, 337, 1078-1081, 2012.

Chen, X., Wang, Z., Yu, F., Pan, X., Li, J., Ge, B., Wang, Z., Hu, M., Yang, W., and Chen, H.: Estimation of atmospheric aging time of black carbon particles in the polluted atmosphere over centraleastern China using microphysical process analysis in regional chemical transport model, Atmos. Environ., 163, 44-56, 2017.

Cooke, W. F. and Wilson, J. J.: A global black carbon aerosol model, J. Geophys. Res.-Atmos., 101, 19395-19409, 1996.

Dahlkötter, F., Gysel, M., Sauer, D., Minikin, A., Baumann, R., Seifert, P., Ansmann, A., Fromm, M., Voigt, C., and Weinzierl, 
B.: The Pagami Creek smoke plume after long-range transport to the upper troposphere over Europe - aerosol properties and black carbon mixing state, Atmos. Chem. Phys., 14, 6111-6137, https://doi.org/10.5194/acp-14-6111-2014, 2014.

De Nazelle, A., Fruin, S., Westerdahl, D., Martinez, D., Ripoll, A., Kubesch, N., and Nieuwenhuijsen, M.: A travel mode comparison of commuters' exposures to air pollutants in Barcelona, Atmos. Environ., 59, 151-159, 2012.

Draxler, R. R. and Hess, G. D.: An overview of the HYSPLIT_4 modeling system for trajectories, dispersion and deposition, Austr. Met. Mag., 47, 295-308, 1998.

Ervens, B., Turpin, B. J., and Weber, R. J.: Secondary organic aerosol formation in cloud droplets and aqueous particles (aqSOA): a review of laboratory, field and model studies, Atmos. Chem. Phys., 11, 11069-11102, https://doi.org/10.5194/acp-1111069-2011, 2011.

Ferron, G. A., Haider, B., and Kreyling, W. G.: Inhalation of salt aerosol particles-I. Estimation of the temperature and relative humidity of the air in the human upper airways, J. Aerosol. Sci., 19, 343-363, 1988.

Fuller, K. A., Malm, W. C., and Kreidenweis, S. M.: Effects of mixing on extinction by carbonaceous particles, J. Geophys. Res., 104, 15941-15954, 1999.

Gao, R. S., Schwarz , J. P., Kelly, K. K., Fahey, D. W., Watts, L. A., Thompson, T. L., Spackman, J. R., Slowik, J. G., Cross, E. S., Han, J. H., Davidovits, P., Onasch, T. B., and Worsnop, D. R.: A novel method for estimating light-scattering properties of soot aerosols using a modified single-particle soot photometer, Aerosol Sci. Tech., 41, 125-135, 2007.

Hansen, J., Sato, M., and Ruedy, R.: Radiative forcing and climate response, J. Geophys. Res., 102, 6831-6864, https://doi.org/10.1029/96JD03436, 1997.

Hansen, J., Sato, M. K. I., Ruedy, R., Nazarenko, L., Lacis, A., Schmidt, G. A., Russell, G., Aleinov, I., Bauer, M., Bauer, S., and Bell, N.: Efficacy of climate forcings, J. Geophys. Res., 110, D18104, https://doi.org/10.1029/2005JD005776, 2005.

Hart, J. E., Laden, F., Eisen, E. A., Smith, T. J., and Garshick, E.: Chronic obstructive pulmonary disease mortality in railroad workers, Occup. Environ. Med., 66, 221-226, 2009.

Hasheminassab, S., Ramanathan, N., Ostro, B., and Sioutas, C.: Long-term source apportionment of ambient fine particulate matter $\left(\mathrm{PM}_{2.5}\right)$ in the Los Angeles Basin: A focus on emissions reduction from vehicular sources, Environ. Pollut., 193, 54-64, 2014.

Healy, R. M., Wang, J. M., Jeong, C. H., Lee, A. K., Willis, M. D., Jaroudi, E., Zimmerman, N., Hilker, N., Murphy, M., Eckhardt, S., and Stohl, A.: Light-absorbing properties of ambient black carbon and brown carbon from fossil fuel and biomass burning sources, J. Geophys. Res.-Atmos., 120, 6619-6633, https://doi.org/10.1002/2015jD023382, 2015.

Heo, J., de Foy, B., Olson, M. R., Pakbin, P., Sioutas, C., and Schauer, J. J.: Impact of regional transport on the anthropogenic and biogenic secondary organic aerosols in the Los Angeles Basin, Atmos. Environ., 103, 171-179, https://doi.org/10.1016/j.atmosenv.2014.12.041, 2015.

Hersey, S. P., Craven, J. S., Schilling, K. A., Metcalf, A. R., Sorooshian, A., Chan, M. N., Flagan, R. C., and Seinfeld, J. H.: The Pasadena Aerosol Characterization Observatory (PACO): chemical and physical analysis of the Western Los
Angeles basin aerosol, Atmos. Chem. Phys., 11, 7417-7443, https://doi.org/10.5194/acp-11-7417-2011, 2011.

Intergovernmental Panel on Climate Change (IPCC): the physical science basis, Contribution of Working Group 1 to the fourth assessment report of the Intergovernmental Panel on Climate Change, edited by: Solomon, S., Qin, D., Manning, M., Chen, Z., Marquis, M., Averyt, K. B., Tignor, M., and Miller, H. L., Cambridge University Press, New York, 2007.

Jacobson, M. Z.: Strong radiative heating due to the mixing state of black carbon in atmospheric aerosols, Nature, 409, 695-697, 2001.

Kirchstetter, T. W. and Novakov, T.: Controlled generation of black carbon particles from a diffusion flame and applications in evaluating black carbon measurement methods, Atmos. Environ., 41, 1874-1888, 2007.

Krasowsky, T. S., Daher, N., Sioutas, C., and BanWeiss, G. A.: Measurement of emission factors from in-use locomotives, Atmos. Environ., 113, 187-196, https://doi.org/10.1016/j.atmosenv.2015.04.046, 2014.

Krasowsky, T. S., Wang, D., McMeeking, G., Sioutas, C., and Ban-Weiss, G. A.: Real-world measurements of the impact of atmospheric aging on physical and optical properties of ambient black carbon particles, Atmos. Environ., 142, 496-504, https://doi.org/10.1016/j.atmosenv.2016.08.010, 2016.

Laborde, M., Mertes, P., Zieger, P., Dommen, J., Baltensperger, U., and Gysel, M.: Sensitivity of the Single Particle Soot Photometer to different black carbon types, Atmos. Meas. Tech., 5, 10311043, https://doi.org/10.5194/amt-5-1031-2012, 2012.

Laborde, M., Crippa, M., Tritscher, T., Jurányi, Z., Decarlo, P. F., Temime-Roussel, B., Marchand, N., Eckhardt, S., Stohl, A., Baltensperger, U., Prévôt, A. S. H., Weingartner, E., and Gysel, M.: Black carbon physical properties and mixing state in the European megacity Paris, Atmos. Chem. Phys., 13, 5831-5856, https://doi.org/10.5194/acp-13-5831-2013, 2013.

Lack, D. A., Cappa, C. D., Cross, E. S., Massoli, P., Ahern, A. T., Davidovits, P., and Onasch, T. B.: Absorption Enhancement of coated absorbing aersols: Validation of the photo-acoustic technique for measuring the enhancement, Aersol Sci. Tech., 43, 1006-1012, https://doi.org/10.1080/02786820903117932, 2009.

Lee, A. K. Y., Chen, C.-L., Liu, J., Price, D. J., Betha, R., Russell, L. M., Zhang, X., and Cappa, C. D.: Formation of secondary organic aerosol coating on black carbon particles near vehicular emissions, Atmos. Chem. Phys., 17, 15055-15067, https://doi.org/10.5194/acp-17-15055-2017, 2017.

Lim, Y. B., Tan, Y., Perri, M. J., Seitzinger, S. P., and Turpin, B. J.: Aqueous chemistry and its role in secondary organic aerosol (SOA) formation, Atmos. Chem. Phys., 10, 1052110539, https://doi.org/10.5194/acp-10-10521-2010, 2010.

Liu, D., Allan, J. D., Young, D. E., Coe, H., Beddows, D., Fleming, Z. L., Flynn, M. J., Gallagher, M. W., Harrison, R. M., Lee, J., Prevot, A. S. H., Taylor, J. W., Yin, J., Williams, P. I., and Zotter, P.: Size distribution, mixing state and source apportionment of black carbon aerosol in London during wintertime, Atmos. Chem. Phys., 14, 10061-10084, https://doi.org/10.5194/acp-1410061-2014, 2014.

Lloyd, A. C. and Cackette, T. A.: Diesel engines: environmental impact and control, J. Air Waste Manage. Assoc., 51, 809-847, 2001. 
Lough, G. C., Schauer, J. J., and Lawson, D. R.: Day-of-week trends in carbonaceous aerosol composition in the urban atmosphere, Atmos. Environ., 40, 4137-4149, 2006.

Marr, L. C. and Harley, R. A.: Modeling the effect of weekdayweekend differences in motor vehicle emissions on photochemical air pollution in central California, Environ. Sci. Technol., 36, 4099-4106, 2002.

Massoli, P., Fortner, E. C., Canagaratna, M. R., Williams, L. R., Zhang, Q. Sun, Y., Schwab, J. J., Trimborn, A., Onasch, T. B., Demerjian, K. L., Kolb, C. E., Worsnop, D. R., and Jayne, J. T.: Pollution gradients and chemical characterization of particulate matter from vehicular traffic near major roadways: results from the 2009 Queens College Air Quality Study in NYC, Aerosol Sci. Tech., 46, 1201-1218, 2012.

McMeeking, G. R., Morgan, W. T., Flynn, M., Highwood, E. J., Turnbull, K., Haywood, J., and Coe, H.: Black carbon aerosol mixing state, organic aerosols and aerosol optical properties over the United Kingdom, Atmos. Chem. Phys., 11, 9037-9052, https://doi.org/10.5194/acp-11-9037-2011, 2011.

Metcalf, A. R., Craven, J. S., Ensberg, J. J., Brioude, J., Angevine, W., Sorooshian, A., Duong, H. T., Jonsson, H. H., Flagan, R. C., and Seinfeld, J. H.: Black carbon aerosol over the Los Angeles Basin during CalNex, J. Geophys. Res.-Atmos., 117, D00V13, https://doi.org/10.1029/2011JD017255, 2012.

Moteki, N. and Kondo, Y.: Effects of mixing state on black carbon measurements by laser-induced incandescence, Aerosol Sci. Tech., 41, 398-417, 2007.

Pollack, I. B., Ryerson, T. B., Trainer, M., Parrish, D. D., Andrews, A. E., Atlas, E. L., Blake, D. R., Brown, S. S., Commane, R., Daube, B. C., and Gouw, J. A.: Airborne and ground-based observations of a weekend effect in ozone, precursors, and oxidation products in the California South Coast Air Basin, J. Geophys. Res.-Atmos., 117, D00V05, https://doi.org/10.1029/2011JD016772, 2012.

Riemer, N., Vogel, H., and Vogel, B.: Soot aging time scales in polluted regions during day and night, Atmos. Chem. Phys., 4, 1885-1893, https://doi.org/10.5194/acp-4-1885-2004, 2004.

Riemer, N., West, M., Zaveri, R., and Easter, R.: Estimating black carbon aging time-scales with a particle-resolved aerosol model, J. Aerosol Sci., 41, 143-158, 2010.

Sardar, S., Fine, P., and Sioutas, C.: Seasonal and spatial variability of the size-resolved chemical composition of particulate matter $\left(\mathrm{PM}_{10}\right)$ in the Los Angeles Basin, J. Geophys. Res.-Atmos., 110, D07S08, https://doi.org/10.1029/2004JD004627, 2005.

Schwarz, J. P., Gao, R. S., Spackman, J. R., Watts, L. A., Thomson, D. S., Fahey, D. W., Ryerson, T. B., Peischl, J., Holloway, J. S., Trainer, M., and Frost, G. J.: Measurement of the mixing state, mass, and optical size of individual black carbon particles in urban and biomass burning emissions, Geophys. Res. Lett., 35, L13810, https://doi.org/10.1029/2008GL033968, 2008a.

Schwarz, J. P., Spackman, J. R., Fahey, D. W., Gao, R. S., Lohmann, U., Stier, P., Watts, L. A., Thomson, D. S., Lack, D. A., Pfister, L., and Mahoney, M. J.: Coatings and their enhancement of black carbon light absorption in the tropical atmosphere, J. Geophys. Res.-Atmos., 113, D03203, https://doi.org/10.1029/2007JD009042, 2008b.

Schwarz, J. P., Perring, A. E., Markovic, M. Z., Gao, R. S., Ohata, S., Langridge, J., Law, D., McLaughlin, R., and Fahey, D. W.: Technique and theoretical approach for quantifying the hygro- scopicity of black-carbon-containing aerosol using a single particle soot photometer, J. Aerosol Sci., 81, 110-126, 2014.

Sedlacek, A. J., Lewis, E. R., Kleinman, L., Xu, J., and Zhang, Q.: Determination of and evidence for non-core-shell structure of particles containing black carbon using the Single-Particle Soot Photometer (SP2), Geophys. Res. Lett., 39, L06802, https://doi.org/10.1029/2012GL050905, 2012.

Shiraiwa, M., Kondo, Y., Moteki, N., Takegawa, N., Sahu, L. K., Takami, A., Hatakeyama, S., Yonemura, S., and Blake, D. R.: Radiative impact of mixing state of black carbon aerosol in Asian outflow, J. Geophys. Res.-Atmos., 113, D24210, https://doi.org/10.1029/2008JD010546, 2008.

Subramanian, R., Kok, G. L., Baumgardner, D., Clarke, A., Shinozuka, Y., Campos, T. L., Heizer, C. G., Stephens, B. B., de Foy, B., Voss, P. B., and Zaveri, R. A.: Black carbon over Mexico: the effect of atmospheric transport on mixing state, mass absorption cross-section, and BC/CO ratios, Atmos. Chem. Phys., 10, 219 237, https://doi.org/10.5194/acp-10-219-2010, 2010.

Taylor, J. W., Allan, J. D., Allen, G., Coe, H., Williams, P. I., Flynn, M. J., Le Breton, M., Muller, J. B. A., Percival, C. J., Oram, D., Forster, G., Lee, J. D., Rickard, A. R., Parrington, M., and Palmer, P. I.: Size-dependent wet removal of black carbon in Canadian biomass burning plumes, Atmos. Chem. Phys., 14, 13755-13771, https://doi.org/10.5194/acp-14-137552014, 2014.

Turpin, B. J. and Huntzicker, J. J.: Secondary formation of organic aerosol in the Los Angeles basin: A descriptive analysis of organic and elemental carbon concentrations, Atmos. Environ., 25, 207-215, https://doi.org/10.1016/0960-1686(91)90291-E, 1991.

Turpin, B., Huntzicker, J., and Hering, S.: Investigation of organic aerosol sampling artifacts in the Los Angeles Basin, Atmos. Environ., 28, 3061-3071, 1994.

Venkatachari, P., Hopke, P. K., Grover, B. D., and Eatough, D. J.: Measurement of particle-bound reactive oxygen species in rubidoux aerosols, J. Atmos. Chem., 50, 49-58, 2005.

Wang, Q., Huang, R. J., Cao, J., Han, Y., Wang, G., Li, G., Wang, Y., Dai, W., Zhang, R., and Zhou, Y.: Mixing State of Black Carbon Aerosol in a Heavily Polluted Urban Area of China: Implications for Light Absorption Enhancement, Aerosol Sci. Tech., 48, 689697, https://doi.org/10.1080/02786826.2014.917758, 2014.

Warneke, C., Gouw, J. A., Edwards, P. M., Holloway, J. S., Gilman, J. B., Kuster, W. C., Graus, M., Atlas, E., Black, D., Gentner, D. R., and Goldstein, A. H.: Photochemical aging of volatile organic compounds in the Los Angeles basin: Weekday-weekend effect, J. Geophys. Res.-Atmos., 118, 50185028, https://doi.org/10.1002/jgrd.50423, 2013.

Weather Underground Redlands: Weather History for Redlands, CA and Santa Monica, CA available at: http://www.wunderground. com/history, last access: October 2016.

Weingartner, E., Burtscher, H., and Baltensperger, U.: Hygroscopic properties of carbon and diesel soot particles, Atmos. Environ., 31, 2311-2327, 1997.

Willis, M. D., Healy, R. M., Riemer, N., West, M., Wang, J. M., Jeong, C.-H., Wenger, J. C., Evans, G. J., Abbatt, J. P. D., and Lee, A. K. Y.: Quantification of black carbon mixing state from traffic: implications for aerosol optical properties, Atmos. Chem. Phys., 16, 4693-4706, https://doi.org/10.5194/acp16-4693-2016, 2016. 
World Health Organization (WHO): Health effects of black carbon, ISBN: 9789289002653, available at: http://www.euro.who.Int/_ data/assets/pdf_file/0004/162535/e96541.pdf (last access: 6 August 2018), 2012.

Zhang, K. M., Wexler, A. S., Zhu, Y. F., Hinds, W. C., and Sioutas, C.: Evolution of particle number distribution near roadways, Part II: the "Road-to-Ambient" process, Atmos. Environ., 38, 6655$6665,2004$.
Zhang, J., Liu, J., Tao, S., and Ban-Weiss, G. A.: Long-range transport of black carbon to the Pacific Ocean and its dependence on aging timescale, Atmos. Chem. Phys., 15, 11521-11535, https://doi.org/10.5194/acp-15-11521-2015, 2015.

Zhu, Y., Hinds, W. C., Kim, S., and Sioutas, C.: Concentration and size distribution of ultrafine particles near a major highway, J. Air Waste Manage. Assoc., 52, 1032-1042, 2002. 